\title{
Determinants of Government Budget Deficit in the Economy of Iran Emphasizing the Economic and Political Economic Factors
}

\author{
Alireza Saedi Sarkhanlou ${ }^{1}$ \\ Hassan Dargahï ${ }^{2}$ \\ saedi@ndf.ir \\ h-dargahi@sbu.ac.ir
}

Received: 03/03/2021 | Accepted: 16/06/2021

\begin{abstract}
In order to implement structural reform in the government budget of Iran, it is necessary to analyze the budgetary characteristics. This paper attempts to identify the determinants of budget deficit by using ARDL modeling based on the Iranian budget records for the period 1964-2020. Theoretical and empirical evidence both show that three main factors including budgeting structure, macroeconomic situation, and political economic forces could play a definite role in the budget deficit. Long term estimated coefficients of the research models explain that budget deficit will be worsened with bigger size of government, and with the increase in the government expenditure dispersion in comparison with the government revenues dispersion, also with a bigger share of public investment in total investment, and finally with wider GDP gap and inflation gap. Correspondingly, more inequality of income leads to a bigger deficit. The results also indicate that in the economy of Iran expenditures are a driving force that brings about the budget deficit. It is evident that in a resource-based economy, an increase in revenues of resource exports would relocate the economy to the positive output gap and boom cycle that in turn will push governments to a higher level of expenditures and a budget deficit. During the recession period in which government revenues decline, the recurrent expenditures resist adjustment due to its sticky behavior, hence the deficit gets worse. Meanwhile, political economic factors such as weakness of the government power and pressure by interest groups, all together have magnifying effects on worsening the budget deficit. During the era that foreign reserves in Stabilization Account and National Development Fund were enough to compensate deficits, the presence of the wealth effect on government expenditures, and thus on the budget deficit, is confirmed.
\end{abstract}

Keywords: Government Budget, Budget Deficit, Government Expenditure, Political Economy, Economy of Iran.

JEL Classification: E62, H61, H62, E32.

1. Ph.D. Student of Economics, Faculty of Economics and Political Sciences, Shahid Beheshti University, Iran.

2. Associate Professor, Faculty of Economics and Political Sciences, Shahid Beheshti University, Iran (Corresponding Author). 


\section{تبيين عوامل موثر بر كسرى بودجه در ايران باديا

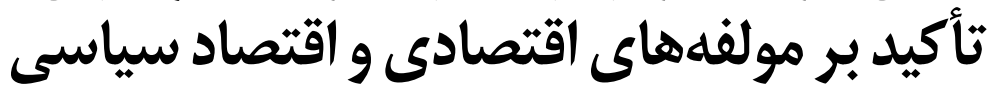

saedi@ndf.ir

dargahi@sbu.ac.ir

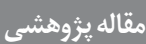

عليرضا ساعدى سارخانلو

دانشجوى دكترى اقتصاد دانشكده اقتصاد و علوم سياسى، دانشاء ساه شهيد

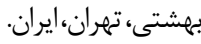

حسن دركاهى دانشيار دانشكده اقتصاد و علوم سياسى، دانشعاه شهيد بهشتى،

تهران، ايران (نويسنده مسئول). |ذيرش:

جكيده: به منظور اصلاح ساختار بودجه عمومى دولت در اقتصاد ايران، شناخت ويزگى هاى

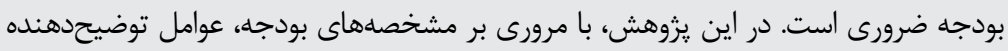

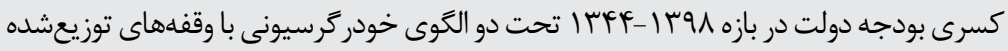
مورد بررسى قرار مى كيرند. شواهد نظرى و تجربى نشان مى دهى دهد كه سه مجموعه عوامل ساختارى

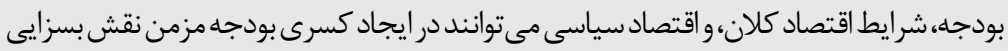

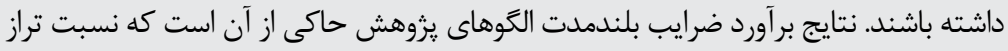

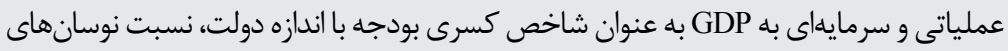

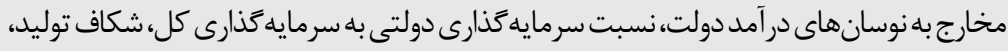

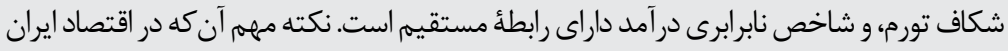

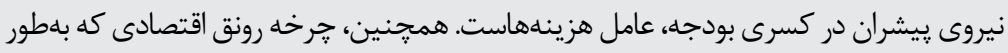

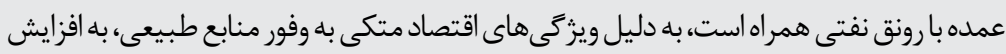

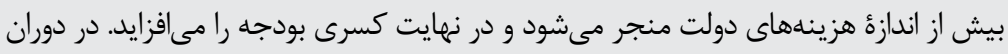

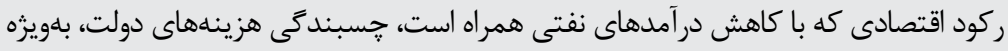

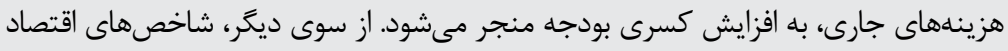

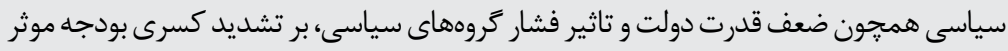

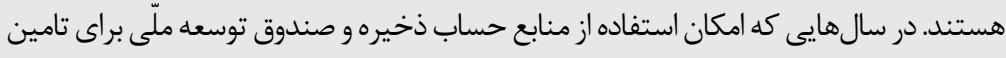
كسرى بودجه فراهم بوده، اثر ثروت بر تشديد كسرى بودجه تاييد شده است

كليدوازهها: بودجه دولت، كسرى بودجه، مخارج دولت، اقتصاد سياسى، اقتصاد ايران. طبقدبندى E62, H61, H62, E32 :JEL. 


\section{مقدمه}

سياست مالى نقش مهمىى در مديريت اقتصادى كشورهاى توسعهيافته و در حال توسعه دارد.

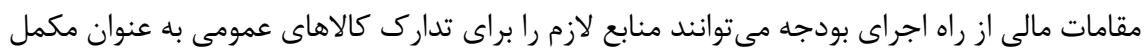
سرمايه خصوصى و تشكيل سرمايه انسانى تجهيز كنند. براى پيادهسازى موفق سياست مالى، دولتها بايد توانايى كسب درآمد كافى براى انجام مخارج داشته باشند. با اين حال، دولتها بهندرت در عمل

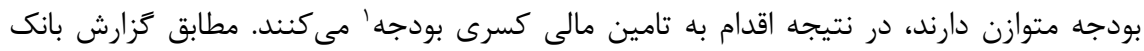

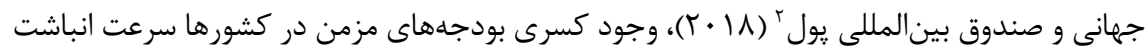
بدهى دولت را افزايش داده است.

در ساليان گذشته، همواره كسرى بودجه به عنوان يك يديده ثابت در اقتصاد ايران قابلمشاهده

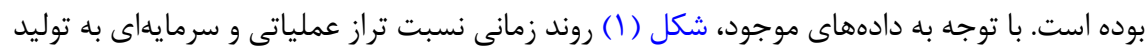

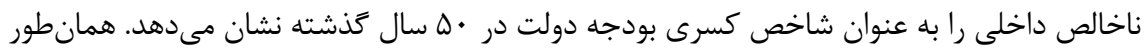
كه مشاهده مىشود، مشخصأ عمده اين دوران، استمرار كسرى بودجه و در عين حال نوسان شديد

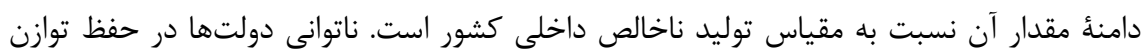

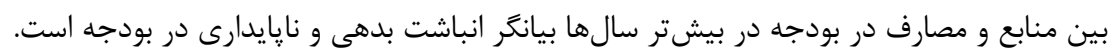

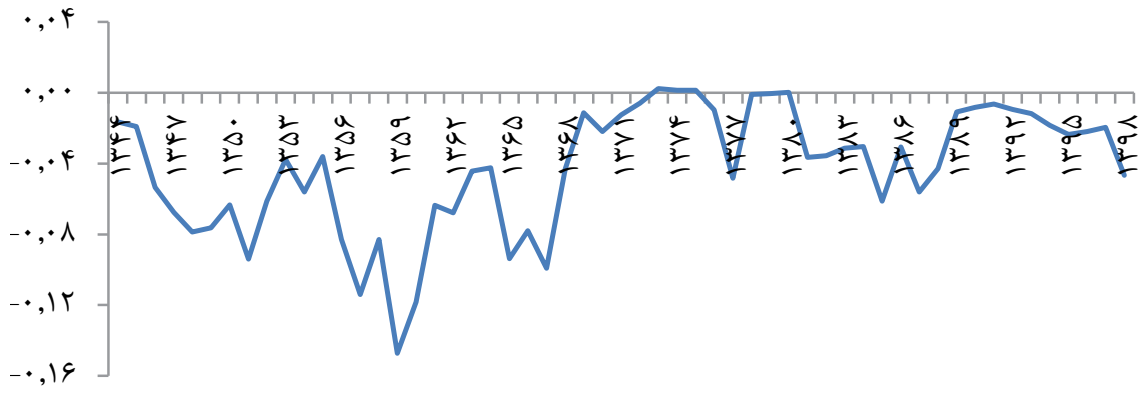

شكل ا: نسبت تراز عملياتى و سرمايهاى به توليد ناخالص داخلى آنلى

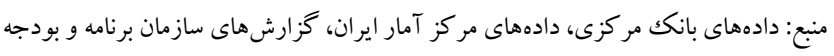

ا. براى تعريف كسرى بودجه مراجعه شود به: (Irwin 2015) و (Hagemann 1999). 2. https://www.un.org/en/ga/second/73/imf-wbg-presentation_debt-vulnerabilities-event.pdf 
نوسانهاى مالى دولت ناشى از بروز مجموعهاى از تحولهاى اقتصادى و سياسى داخلى و خارجى است كه بهنحوى بر ناترازى بودجه همان سال يا سالهاى بعد تاثيرگذار بودهاند. به نظر مىرسد

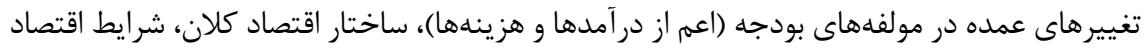

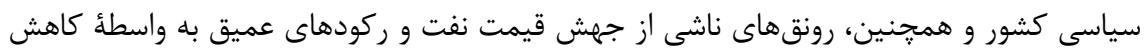
صدور نفت و شوى سالهاى انقلاب، جنى تحميلى، و تحريمها مهمترين عوامل موثر كسرى بودجه بهمار مىروند.

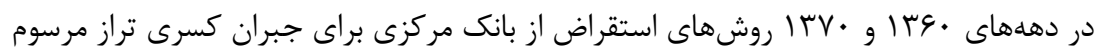

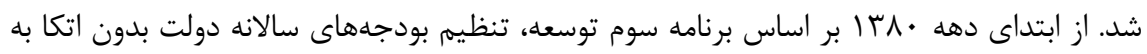

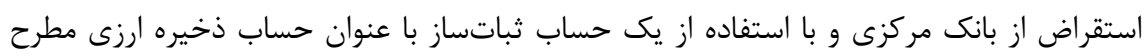
شد و همراه با افزايش مستمر قيمت نفت و تحقق منابع بودجه عمومى دولت در سطحى بالاتر از باز بال

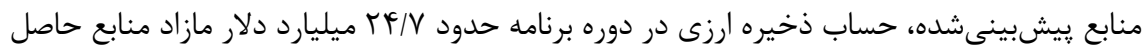

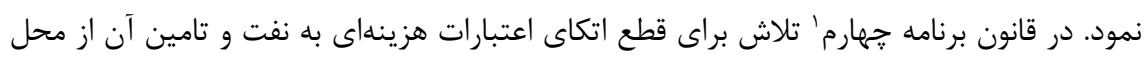

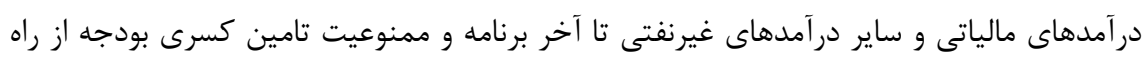

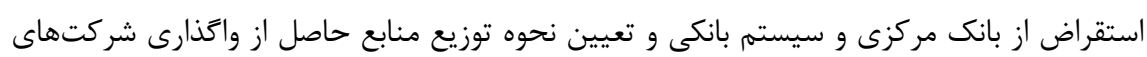

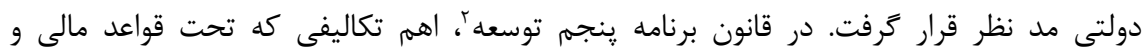

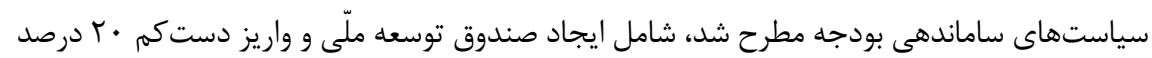

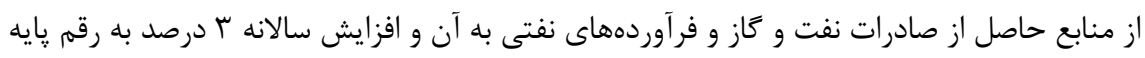

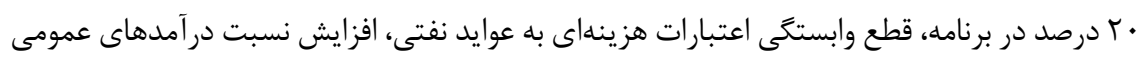

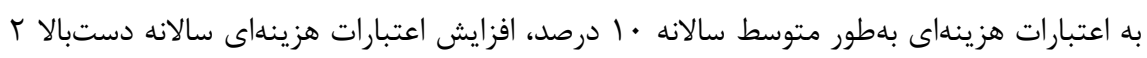
درصد كمتر از نرخ تورم، و ممنوعيت تامين كسرى بودجه از محل استقراض از بانك مركزى و سيستهم بانكى. بهرغم سياستهاى يادشده، كماكان كسرى بودجه در كل دوره به قوت خود باقى ماند مانده است.

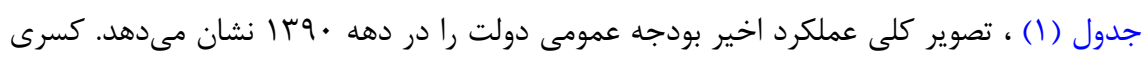
تراز عملياتى و سرمايهاى در تمامى اين دوره به صورت مزمن ادامه داشته و افزايش يافته است.

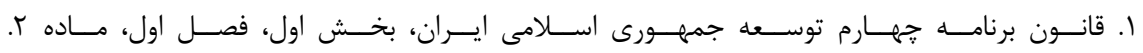
https://rc.majlis.ir/fa/law/show/94202 https://rc.majlis.ir/fa/law/show/790196. r قانون برنامه ينجمم توسعه جمهورى اسلامى ايران، ماده 


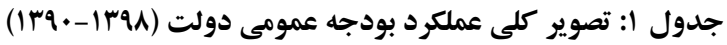

\begin{tabular}{|c|c|c|c|c|c|c|c|c|c|}
\hline IrqA & IrqV & Irag & Irad & irgp & rar & Irar & $|r q|$ & irq. & عنوان / سال \\
\hline rIVINAD & $1 \wedge r \wedge \cdot V q$ & 19V9.r & $149.9 \Delta \Delta$ & IITHYFA & qVVDqF & $\varepsilon \wedge \Delta \wedge \cdot V$ & GOHTqV & 9.999. & در آمدها \\
\hline $19198 \cdot 0$ & $|r g F| \cdot V$ & I & $1 \cdot \mid k V \cdot F$ & $\vee 91 \wedge 9$. & $V \cdot 9 ९ \Delta T$ & FqFTQ. & $F \Delta F \ldots F$ & F. FFFT & درآمدهاى مالياتى \\
\hline$I F \Psi \cdot V \wedge \Delta$ & $1 \cdot V G V M F$ & 941991 & ATIVGD & SVGTFA & DVGYTG & FITADT & $m F \cdot G F d$ & r.c011 & مالياتها \\
\hline 1119\%. & IAVRVR & TREVIF & Iиrquq & $11 \Delta \Delta F T$ & ITHETS & $\Lambda \cdot r q \Lambda$ & I 11 Traq & q४१५। & حقوق ورودى \\
\hline$\Delta \Delta T \backslash \Lambda$. & $\Delta V Y q \hookrightarrow q$ & $\Delta I V G \Delta \Lambda$ & FYQ9Q1 & 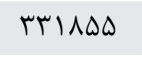 & TEVqFT & $191 \Delta \Delta V$ & 199९9r & $r \cdot \Delta \Delta r \wedge$ & ساير در آمدها \\
\hline$r F \cdot r \wedge \Delta r$ & TVGVTMA & TFYqRVI & $r \cdot V \cdot I V V$ & $1 V \cdot 9 \Lambda \cdot \Delta$ & IFMNTIS & II $9 V A F V$ & $q 9 \vee 1 \Delta r$ & 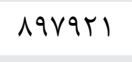 & 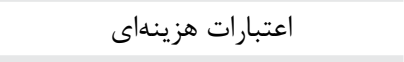 \\
\hline -IKTYQSV & -qrqTGr & -VDHrM & $-Q \cdot 9 \Delta T r$ & $-\Delta \wedge \varepsilon \cdot \varepsilon$. & -FG.VTr & $-\Delta|| N F$. & - MFMNDD & -rAVquI & تراز عملياتى \\
\hline$\Delta \Delta १ \Delta १ \Psi$ & $11 \cdot 9 r \mid r$ & qrTAVV & VETVGq & sVruVq & s $19 \cdot V$ & gFTEFY & 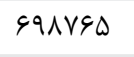 & $\Delta q \cdot V 11$ & واگذارى دارايىهاى سرمايهاى \\
\hline 01919. & $11 \cdot \Delta F T \Lambda$ & 919TrG & VTANIq & $\varepsilon V \cdot r \Delta F$ & घrar.s & $q 4 \cdot 9 V V$ & 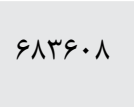 & $\Delta V \| 11$ & اجزاى واگذارى حاصل از نفت و خاز \\
\hline س & rVAd & 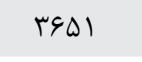 & щq१. & rtra & $r v \cdot 1$ & T\&9V & $|\Delta| \Delta V$ & 19094 & سرمايهاى فروش اموال و ساير \\
\hline DFTTVD & 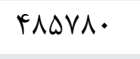 & FI9TDG & 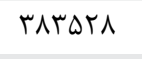 & r\$q.VI & rVArdr & אسזr • & rAfq.r & ryqufq & تملك دارايىهاى سرمايهاى \\
\hline$|я T| 1$ & משTMT & D. TEYI & rब9rVI & $F \cdot F \Delta \cdot \Lambda$ & $r \Delta r \Delta \Delta \Delta$ & $F F \cdot T I I$ & rIfIgr & $r F \cdot 9 G r$ & تراز دارايىهاى سرمايهاى \\
\hline-1 TIS\&49 & $-r \cdot \Delta \wedge r q$ & -rFqVIV & $-Y \cdot \Delta Y \Delta I$ & $-1 \Lambda \mid \Delta \Delta T$ & $-1 \cdot V 19 V$ & $-V I \Delta T q$ & -rq९qu & -49999 & جمع تراز عملياتى و سرمايهاى \\
\hline
\end{tabular}


به منظور اصلاح ساختار بودجه عمومى دولت در اقتصاد ايران، شناخت ويزگى هاى بودجه و عوامل موثر بر كسرى بودجه دولت ضرورى است. هدف اين يروهش شناسايى مههمترين موارد موثر بر ناترازى بودجه دولت است. به اين منظور، سه مجموعه عوامل ساختارى بودجه، شرايط محيطى اقتصاد كلان، و همجنين اقتصاد سياسى در تبيين كسرى بودجه مزمن استفاده مىشود. بنابراين، جامعيت

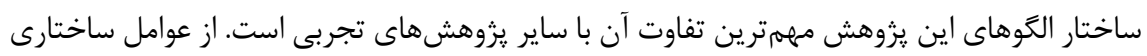

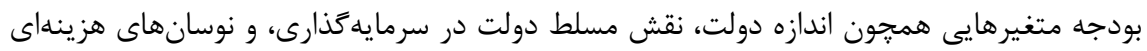

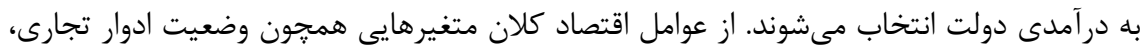
شكاف تورم، و شرايط صندوق توسعه و حساب ذخيره ارزى مورد توجه قرار مى گيرند. از متغيرهاى اقتصاد سياسى شاخص نابرابرى، شاخص قدرت دولت، شاخص فشار گروههاى سياسى، و همجنين آثار شوكهاى سياسى در نظر گرفته مىشوند.

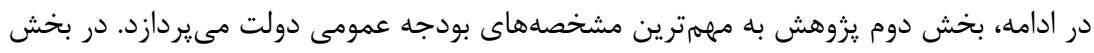

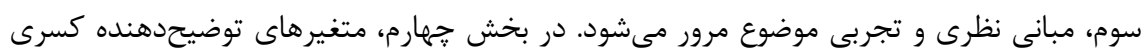

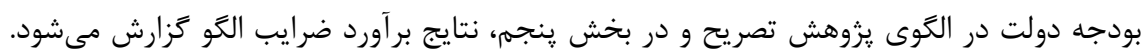
بخش يايانى شامل نتيجه گيرى و جمعبندى است. با توجه به ادبيات نظرى، جهار رويكرد ريكاردويى، كينزى، نئوكلاسيكى، و نظريه جرخه سياسى

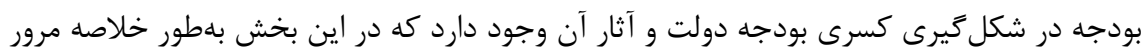

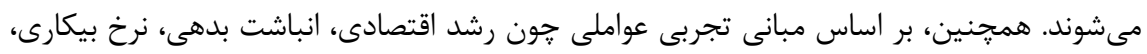
تراز تجارى، مخارج دفاعى، عوامل سياسى، و كيفيت نهادهاى بودجه از تعيينكنندههاى كسرى بودجه بلشمار مى آيند (Mawejje \& Odhiambo, 2020).

\section{نظريه معادل بودن ريكاردويى}

اين نظريه بيان مىكند كه كاهش ماليات و تامين كسرى بودجه، ماليات را تا نسل بعدى به تعويق مىاندازد. به عبارت ديكر، كسرى بودجه جارى نشاندهنده افزايش ماليات در آينده است و بدين جهت داراى اثر حقيقى نيست و در بلندمدت تبعاتى براى متغيرهاى كلان ندارد (Barro, 1974; 1989; Bernheim, 1987; Seater, 1993) در ادامه، نقدهايى بر فروض اين نظريه، 
ازجمله فرض نامحدود بودن عمر خانوارها وارد شد. همجنين، مشاهده شد كه بازارهاى مالى و

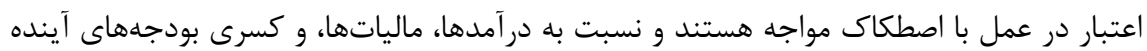
ناطمينانى وجود دارد. از سوى ديخر، اين نظريه فرض مى كند كه اقتصاد در وضعيت اشتغال كامل است و توافقى با فروض الكوى كينزين ها ندارد.

\section{نظريه كينزى}

در رويكرد كينزى به كسرى بودجه، فرض مىشود اقتصاد در شرايط ركودى است و افراد با محدوديت نقدينكى مواجه هستند. بنابراين، مصرف كل به تغييرهاى در آمد قابلتصرف بسيار حساس

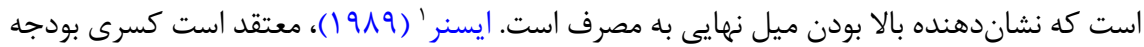
مى تواند با افزايش تقاضاى كل به سرمايهگذارى و رشد بالا منجر شود. او بحث مى كند كه كسرى بودجه به كاهش سرمايهگذارى خصوصى از راه اثر جانشينى جبرى منجر نمى شود، بلكه افزايش

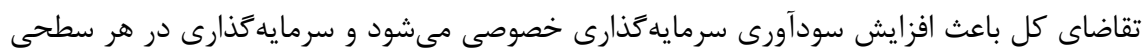

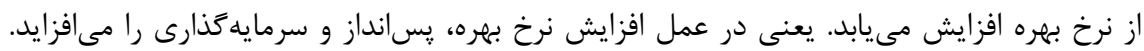

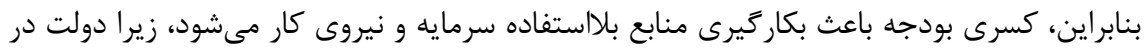

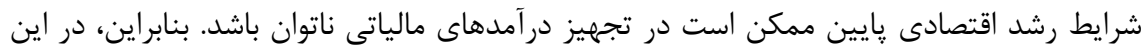

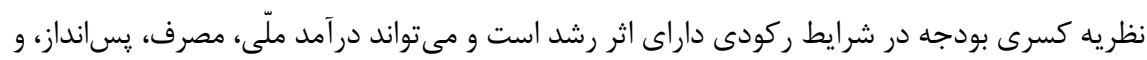
تشكيل سرمايه را بهبود دهد. البته اين نتايج در شرايط اشتغال كامل تغيير مى كند و افزايش كسرى

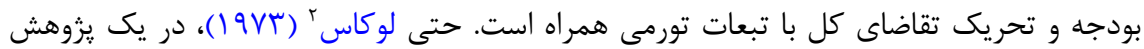

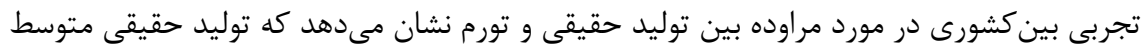
با تحريك تقاضا و تغيير الكوى زمانى نرخ تورم تغييرى نمى كند. در واقع، يك نرخ طبيعى توليد حقيقى وجود دارد.

\section{نظريه نئو كلاسيكى}

الكوى استاندارد نئو كلاسيكى داراى سه ويزًّى اصلى است. يكم، آن كه مصرف هر فرد از راهحل

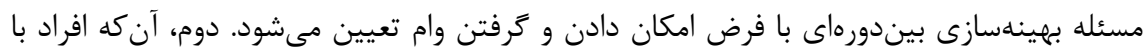


عمر محدود به يك نسل مشخص تعلق دارند كه با نسلهاى ديگر هميوش است. سوم، آن كه بازارها

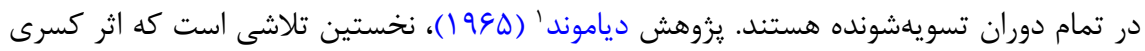

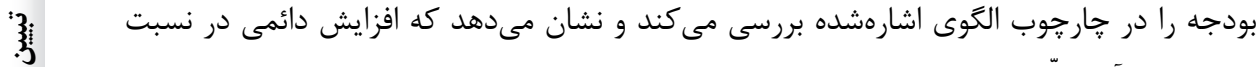
بدهى به درآمد ملّى، به كاهش نرخ سرمايه به نيروى كار در وضعيت يكنواخت منجر مىشود. زئه زيرا كسرى بودجه ماند

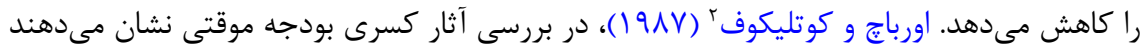
كه كسرى موقتى با فرض تثبيت مخارج دولت، منعكس كننده كاهش ماليات بر سرمايه و نيروى كار

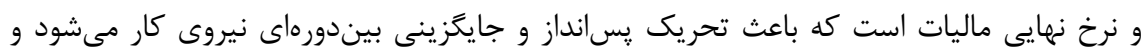

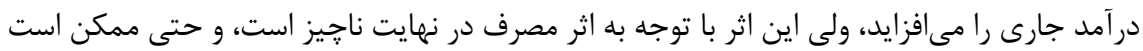

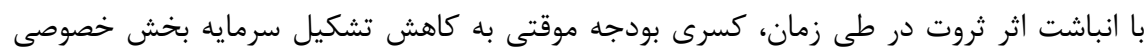
منجر شود.

\section{نظريه جرخه سياسى بودجه}

اين نظريه به اقتصاد سياسى كسرى بودجه مرتبط است كه بر اساس آن تعارضات سياسى منافع، انكَيزهايى را براى سياستمداران (براى مثال يیروزى در انتخابات) در افزايش كسرى بودجه بلهوجود

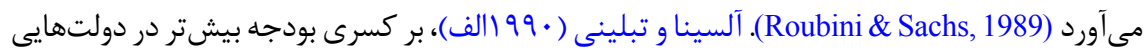
با درجه بالاى تكثرگرايى تاكيد دارند. در خارجوب بحث جرخه سياسى بودجه، جهار نظريه در ادبيات

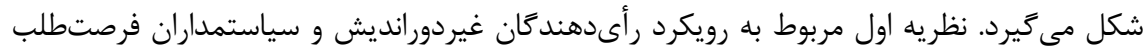

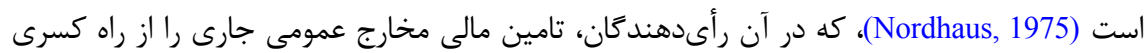
بودجه ارزشمند تلقى مى كنند، ولى هزينههاى آن را از راه افزايش مالياتهاى آتى كم برآورد مي كنيند. نظريه دوم، رويكرد سياستخذاران خارتيزان است (Alesina \& Tabellini, 1990b; Alt \& Lassen, 2006)، كه بر اساس آن ترجيحات غيرهمگن سياستمداران در مورد تركيب مخارج عمومى به كسرى بودجه

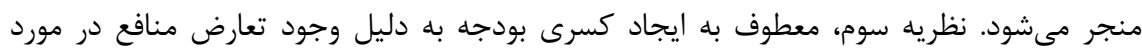

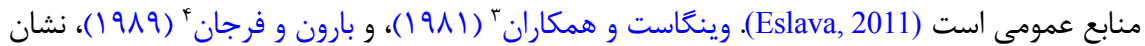

1. Diamond

2. Auerbach \& Kotlikoff

3. Weingast et al.

4. Baron \& Ferejohn 
مى دهند كه تعارضات بازتوزيعى گروههاى مختلفى كه در فرايند بودجه هستند، مىتواند تبعات بودجهاى داشته باشند و در نهايت كسرى بودجه را افزايش دهند (Krogstrup \& Wyplosz, 2010). نظريه اقتصاد سياسى جهارم، بر كيفيت نهادهاى بودجهاى تاكيد دارد. نهادهاى بودجهاى مجموعهاى از قواعد، رويهها،

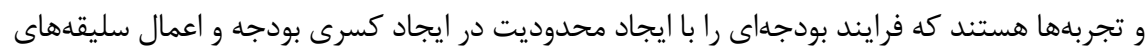
سياسى شكل مى دهند. اين محدوديتها بر اساس تعيين اهداف كمّى بودجه و قواعد بودجهنوينى تعريف مىشوند (Alt \& Lowry, 1994; Alesina \& Perotti, 1999; Hagen, 2002).

\section{مرورى بر مطالعات تجربى}

موريسون' (Y (1))، برخى عوامل نهادى را در كشورهايى كه بهطور مستمر يا اغلب با كسرى بودجه روبهرو هستند مشاهده مى كند و به اين نتيجه مىرسد كه كسرى بودجه بزرىتر رابطه

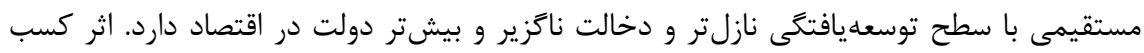

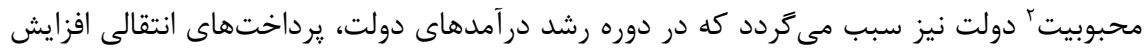

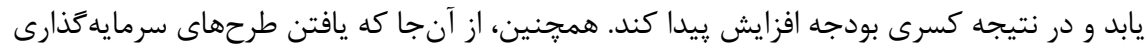

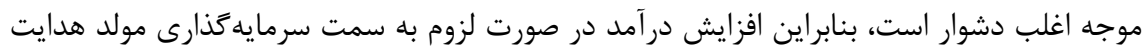
نمىشود و بيشتر به يرداخت رفاهى و جارى تخصيص مى يابد. عامل بىثباتى درآمدهاى دولت نيز با كسرى بودجه دولت رابطه دارد. اين نكته بهويزه در اقتصادهايى داراى اهميت است كه بودجه دولت به درآمدهاى حاصل از تجارت خارجى وابستكى دارد. از سوى ديگر، هرجه نسبت سهرم مخارج

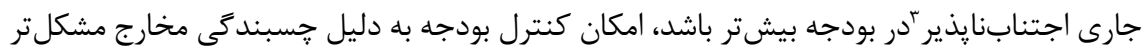
مىشود. براى تبيين امكان كنترليذيرى بودجه از شاخص نسبت نوسانهاى مخارج به نوسانهاى درآمدهاى دولت استفاده مىشود. آر رشد اين نسبت مثبت باشد، نشانكر ريشتازى نوسانهاى

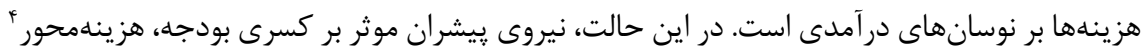

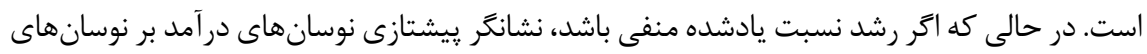

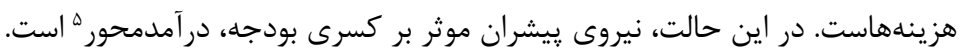

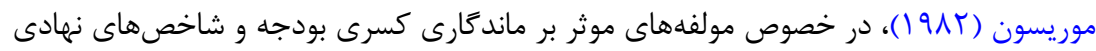

\section{Morrison}

2. Please Effect

3. Recurrent Expenditure

4. Expenditure Follower

5. Revenue Follower 
اقتصادى، به تاثير شاخص سطح توسعهيافتكى بر كسرى بودجه تاكيد دارد. زيرا در اقتصادهايى با سطح پايين يسانداز خصوصى، دولت ملزم به جبران كمبود سرمايهگذارى است. همجنين، سطوح پايين در آمدهاى مالياتى و محدود بودن پايههاى مالياتى به فشار بر مخارج دولت براى ايجاد زيرساخت و خدمات عمومى منجر مىشود. هان و استرم' (99V (19)، در يزّوهش خود در مورد مولفههاى سياسى و اقتصادى موثر بر هزينههاى دولت و كسرى بودجه ابتدا محور بى ثباتى سياسى دولتهاء را مورد توجه مونه قرار مى دهند و بدين منظور سه فرضيه مطرح مى كنند. يكم، آن كه دولتها با افزايش احتمال انتخاب مهري

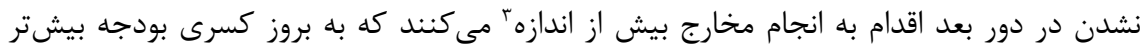

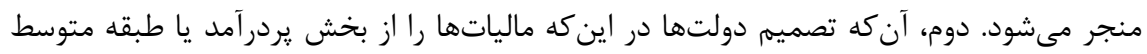

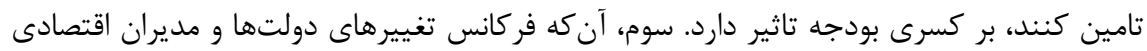
يا سيكلهاى انتخاباتى بر رفتار هزينهاى دولت اثر گذار است. همجنين در يزوهش اشارهشده، موضوع

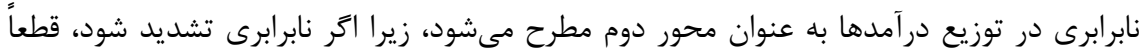

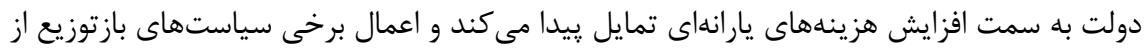

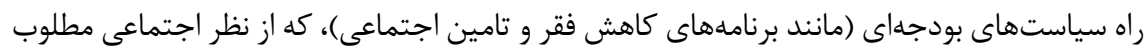
و بر اساس مبانى نظرى نيز جزو اهداف سياست مالى است، مىتواند اثر تزاحمى بر سرمايهگذارى

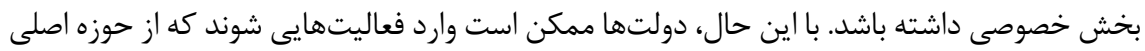
تعريف دولت فاصله دارد و در نتيجه، اخلالهاى مهمى را در درآمدها و مخارج ايجاد مى كنيند. محور سوم، نحوه تركيب ائتلافى احزاب در دولت از راه شاخص توزيع و طيف قدرت است (Roubini, 1991).

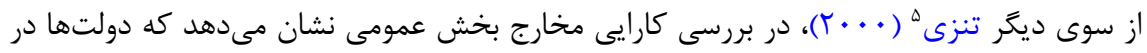

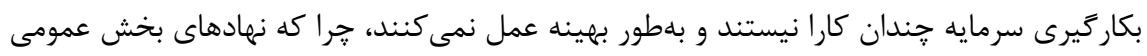
به جهت نبود انكيزه و در نظرنكرفتن هزينه فرصت منابع بلهطور معمول موجب اتلاف منابع مى شوند.

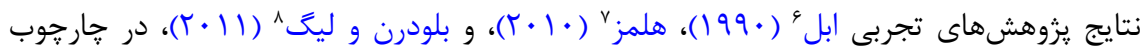
فرضيه كسرىهاى دوكانه نشان مىدهند كه كسرى بودجه و تراز حساب تجارى با هم ارتباط دارند.

1. De Haan \& Sturm

2. Political Instability

3. Overspending

4. Power Dispersion

5. Tanzi

6. Abell

II. Holmes

II 8. Bluedorn \& Leigh 
مالتريتز و ووست' (ها • r)، با بكاركيرى روش دادهاى تركيبى به تعيين عوامل موثر بر كسرى

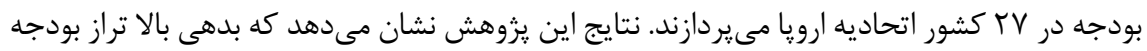

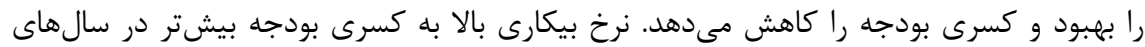
انتخابات منجر مىشود. همجنين، قواعد مالى باطور معنادارى باعث كاهش كسرى بودجه مىشوند. يزوهشهاى مختلفى در مورد كسرى بودجه از منظر اقتصاد سياسى انجام كرفته است. نتايج

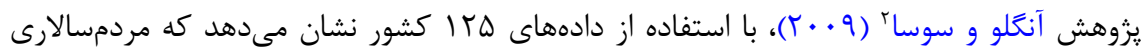
نوسانهاى كسرى بودجه عمومى را كاهش مى بدهد، و بىثباتى سياسى و تورم با نوسانهاى كسرى

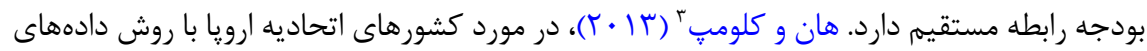

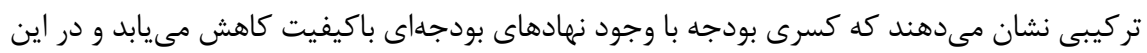
صورت، تنوع گروهها و سليقههاى سياسى مهرم نيست.

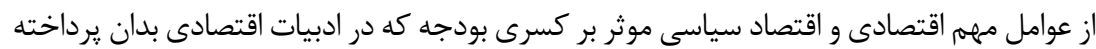
شده است، تاثير شرايط ادوار تجارى" بر كسرى بودجه دولت است. رفتار سياستهاى مالى مالى در عمده

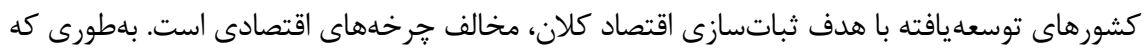
در شرايط رونق به دليل نكرانى از تورم و بحرانهاى اقتصادى و براى كنترل تقاضا، مخارج دولت به

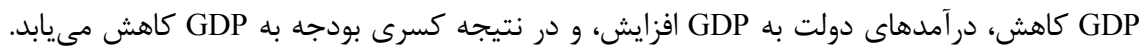

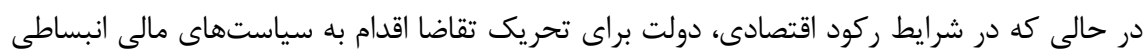
مى كند كه به افزايش كسرى بودجه به GDP منجر مىشود (Alesina et al., 2008). با اين حال، رفتار

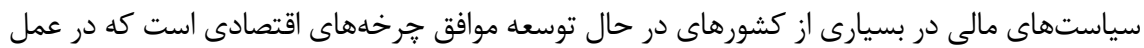

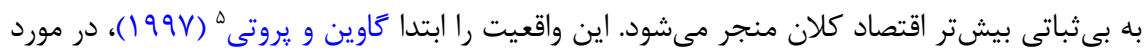

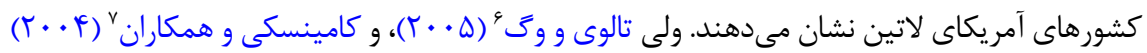

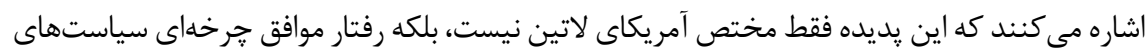

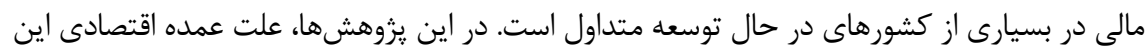

1. Maltritz \& Wüste

2. Agnello \& Sousa

3. De Haan \& Klomp

4. Business Cycles

5. Gavin \& Perotti

6. Talvi \& Vegh

7. Kaminsky et al. 
״ديده در ارتباط با نوسانهاى بالاى پايههاى مالياتى، بخش غيررسمى بزرى در اقتصاد و همجنين،

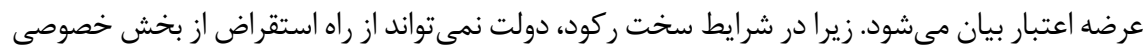
تامين مالى كند و اكر هم بتواند، با نرخ بهره خيلى بالا امكانيذير است. بنابراين، دولت براى مديريت كسرى بودجه مجبور به كاهش مخارج است، در حالى كه در شرايط رونق، دولت اقدام به استقراض

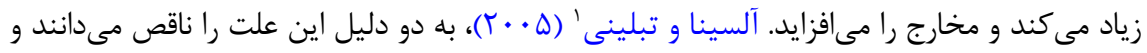
يديده رفتار موافق جرخهاى سياستهاى مالى دولت در اين كشورها را بر مبانى اقتصاد سياسى تفسير

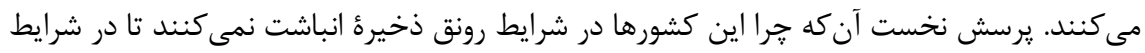

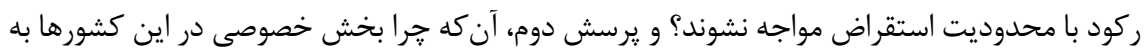
رغم اطلاع از اينكه قرض به دولت در شرايط ركود مىتواند بهينه باشد، از دادن قرض به دولت امتناع

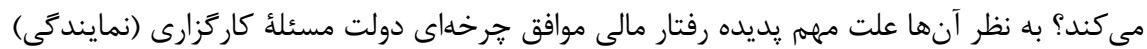

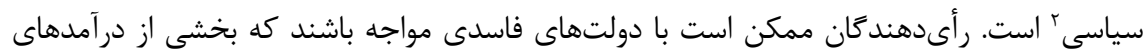
مالياتى راصرف مصارف عمومى غيرمولد يا رانتهاى سياسى در مسير علايق دولت مى كنند. اين مسئله

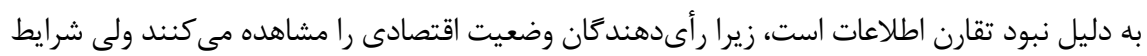

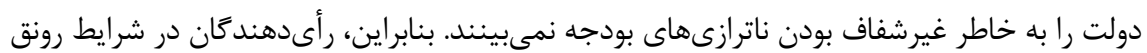
اقتصادى، بيشترين مطلوبيت را براى خود به شكل كاهش ماليات و كالاهاى عمومى بهتر تقاضا مى كنند

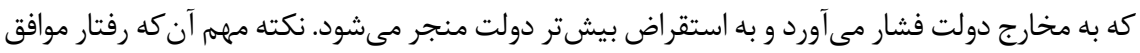

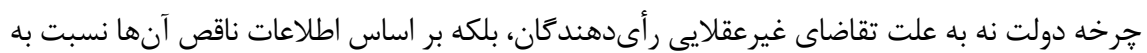
سياستهاى اقتصادى است كه در شرايط فساد اقتصادى و نبود شفافيت سياسى، به عنوان راهحل بهينه دوم، بهجاى تغيير دولت، تقاضاهاى خود را افزايش مى دهند و به آن مى سىسند.

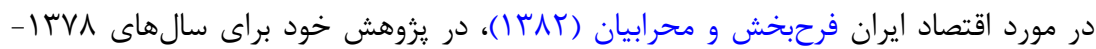

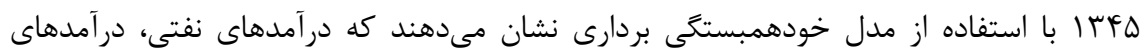

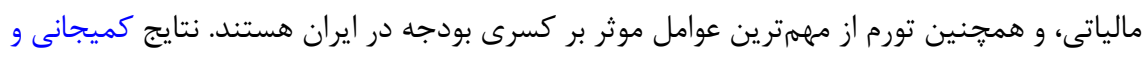

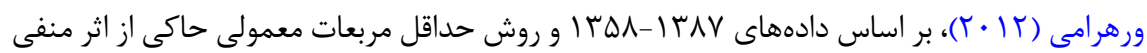

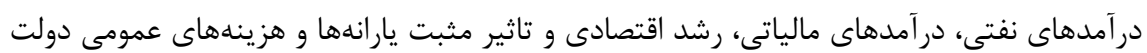

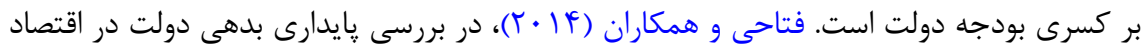


ايران نقش كسرى بودجههاى كذشته را در كسرى بودجه فعلى نشان مىدهند. نتايج اين يزوهش

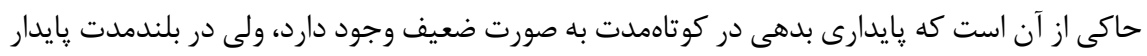
نيست. جهرازى مدرسه و نجاتى (و9 (1)، رابطه شكاف توليد را با بدهى دولت و كسرى بودجه نشان

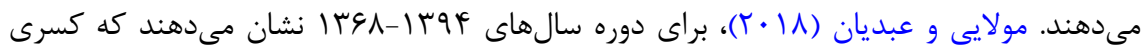
بودجه با در آمدهاى مالياتى، نفتى، و نرخ رشد اقتصادى رابطه منفى و معنادار، و با مخارج دولت و نرخ

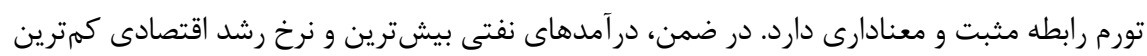

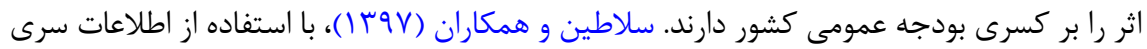

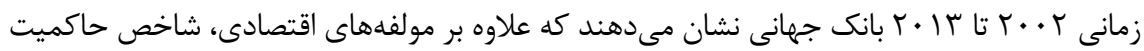

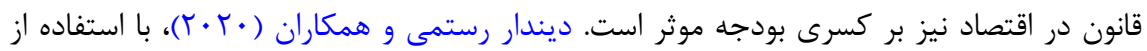

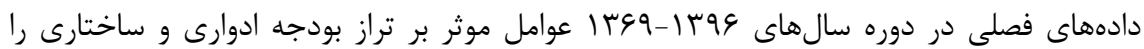

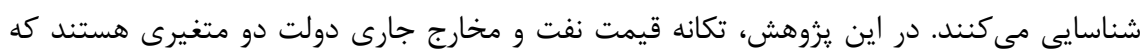

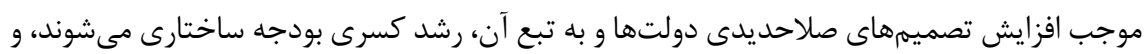

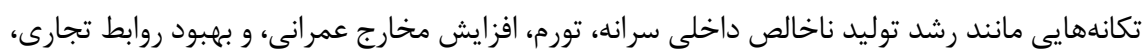
و به تبع آن رابطه مبادله، موجب كاهش كسرى ساختارى مىشوند.

\section{روششناسى يزوهش}

به منظور تصريح الكَى يزوهش ابتدا بايد مههترين زالشهاى بودجه دولت شناسايى شوند.

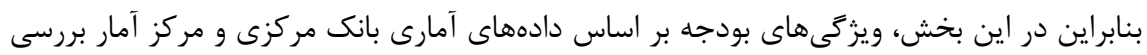
مىشوند، سيس ساختار الخو تبيين مىشود.

\section{بودجه دولت و وابستگى نفتى}

در آسيبشناسى استمرار و نوسان كسرى بودجه دولت، وابستخى نفتى يكى از ويزگى هاى مهم است كه تراز بودجه را در دورههاى گذشته دجار نوسان كرده است. ميانگين نسبت در آمدهاى نفتى به كل مصارف

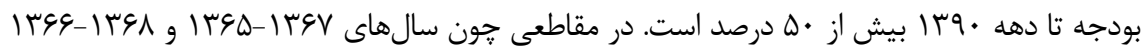

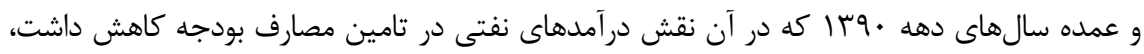


دليل اصلى كاهش در آمد نفتى بود. رابطه تراز عملياتى سرمايهاى با روند سهمم درآمدهاى نفتى به توليد ناخالص داخلى نشانكر همحركتى رفتار كسرى بودجه با نقش نفت در اقتصاد كشور است. اين واقعيت

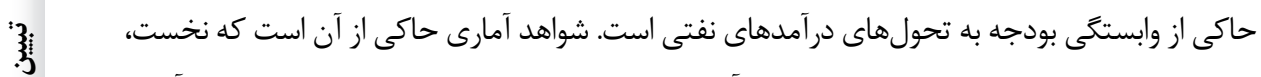
رابطه مستقيمى بين برداختهاى دولت با درآمدهاى حاصل از صادرات نفت وجود دارد. دوم، آنكه

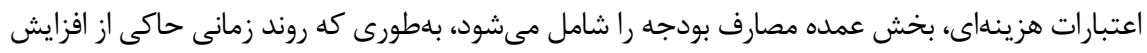

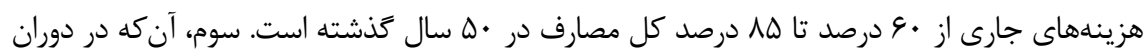
افزايش درآمدهاى نفتى، يرداختهاى هزينهاى با شتابى بيشتر از إز هزينههاى تملك دارايىهاى سرمايهاى

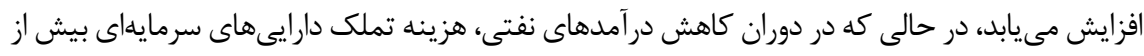

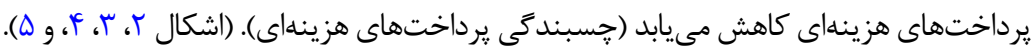

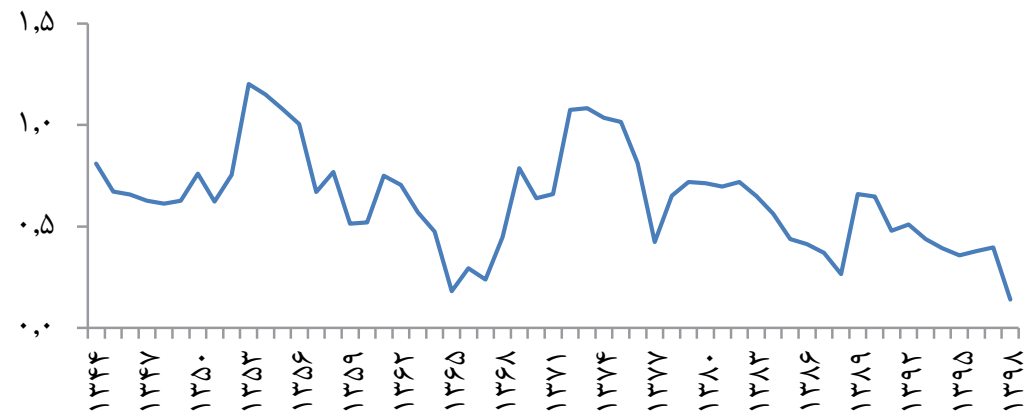

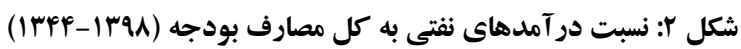

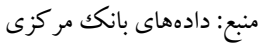




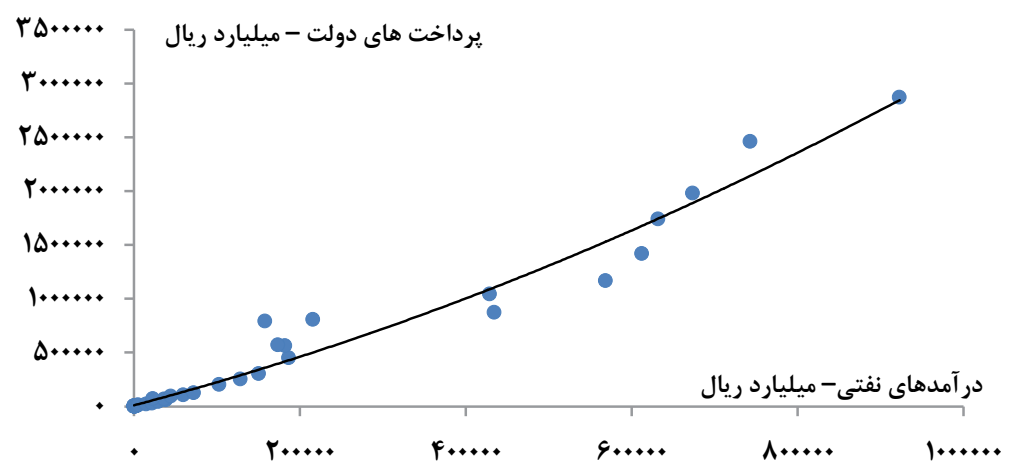

شكل r: رابطه در آمدهاى نفتى و يرداختهاى دولت (1

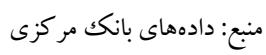

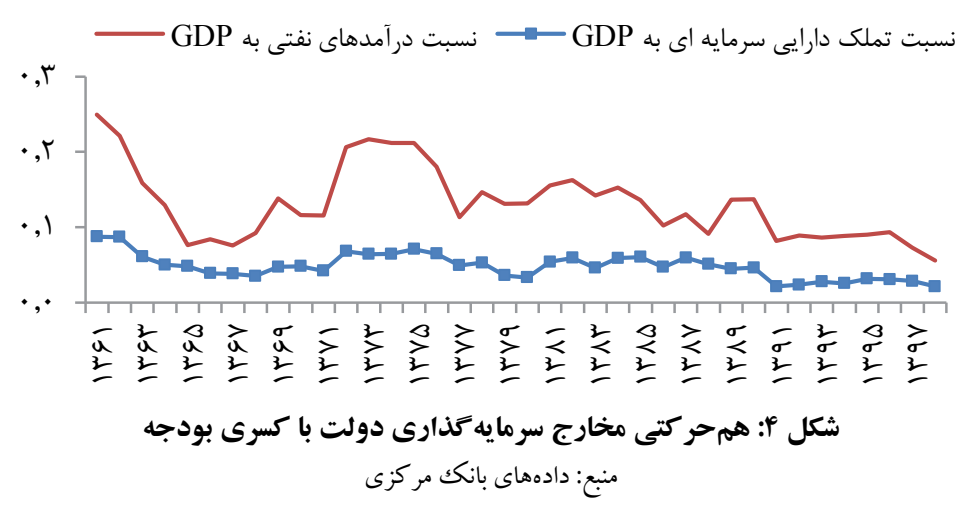

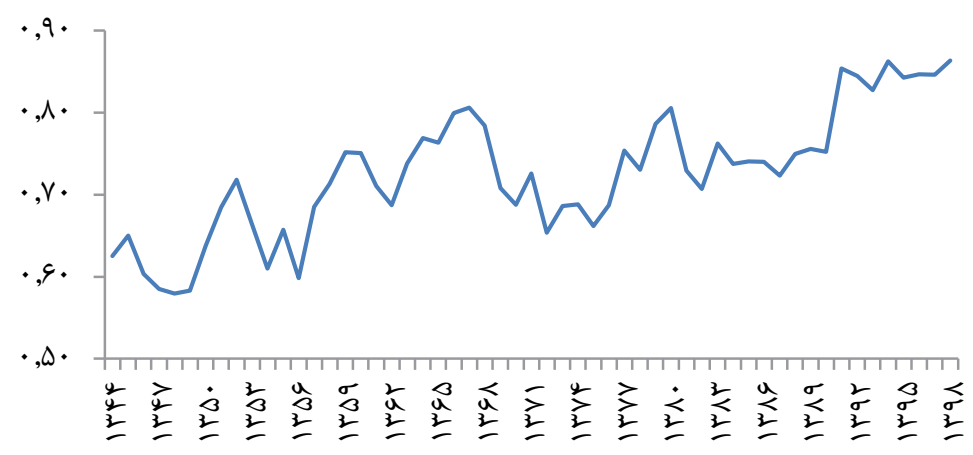
شكل ه: روند افزايشى سهم اعتبارات هزينهاى در كل مصارف 


\section{بودجه دولت و جرخههاى تجارى}

با توجه به همحركتى مخارج دولت با فراز و نشيب درآمدهاى نفتى، سياستهاى بودجهاى در

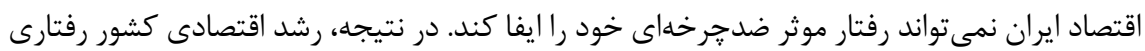
نوسانى از خود نشان مى دهد.

\section{بودجه دولت و سلطه مالى}

در دورههاى تشديد كسرى تراز عملياتى سرمايهاى روش جبران كسرى يكى از مهمترين

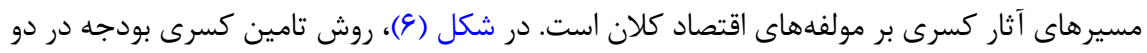

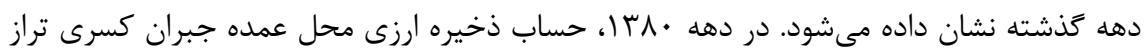

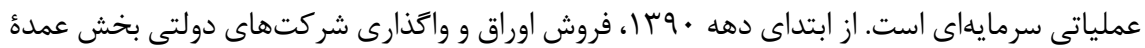

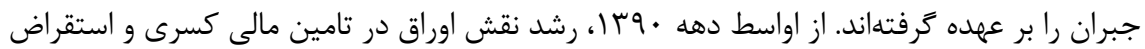

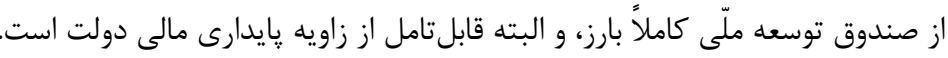


به دنبال افزايش كسرى بودجه، بهويزه از دهه • •ـrا، همواره پايه بولى افزايش يافته، كه نشانگر سلطه مالى بر سياستهاى يولى است، و موجبات استمرار تورم را فراهم كرده و بانك مركزى راله

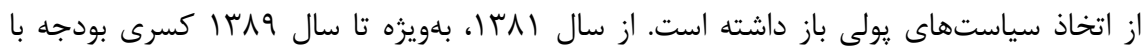
تغييرهاى خالص دارايىهاى خارجى بانى مركزى كاملاً مشابه حركت كرده است و كسرى تراز

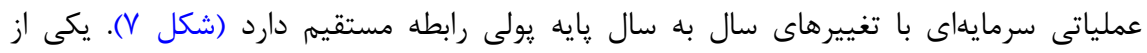
كانالهاى مههم تاثيركذار بر تنش مالى تاثير سياست مالى بر سياست يولى است كه از راه انتشار

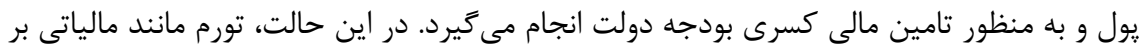
دار ايى هاى : بولى است.

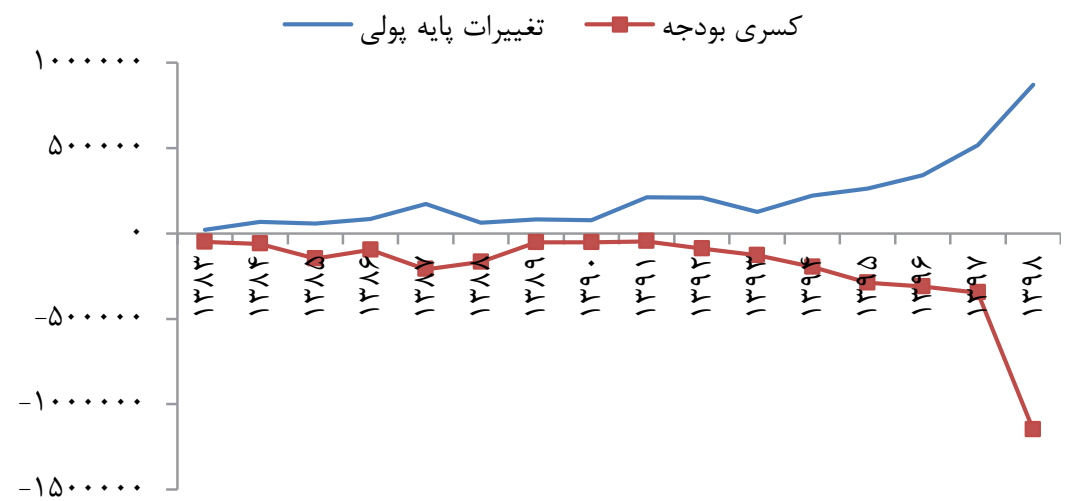

شكل \: رابطه تراز عملياتى و سرمايهاى با تغييرهاى هايه هولى

منبع: دادههاى بانكك مركزى ماني

بودجه دولت و مقياس اقتصاد (اندازه دولت)

مخارج دولت برحسب وظايف حاكميتى شامل مخارج در ده گروه خدمات امور عمومى، دفاع، نظمى و امنيت عمومى، امور اقتصادى، حفاظت از محيطزيست، مسكن و تسهيلات شهرى، بهداشت و درمان، تفريح و فرهنگ و مذهب، آموزش، و حمايت اجتماعى طبقهبندى مى شود. نسبت مخارج دولت به توليد ناخالص داخلى شاخصى براى اندازه دولت است. ميانكين مقدار اين شاخص بر براى ايران

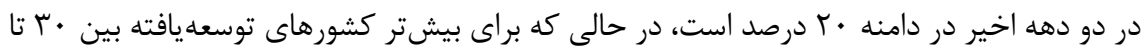


هه درصد است (شكل ^). اين واقعيت نشان مىدهد كه در اقتصاد ايران، بهرغم دخالتهاى گسترده دولت در اقتصاد، اندازه دولت در حوزه وظايف حاكميتى كوجى، ولى در حوزه تصدى درى برى بزرى است. در اقتصاد ايران همسو با مبانى نظرى، رابطه بين اندازه دولت و رشد اقتصادى به صورت U ل معكوس است. يعنى تا سطح بهينهاى بزرگتر شدن اندازه دولت مىتواند رشد اقتصادى را افزايش

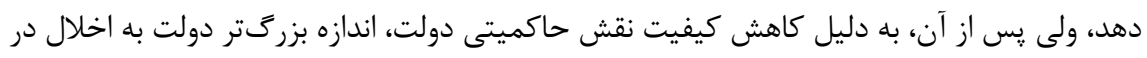
رشد اقتصادى منجر مىشود (شكل 9). شكل (• ())، رابطه مستقيه اندازه دولت در ايران را با نسبت دهيت كسرى بودجه به توليد ناخالص داخلى نشان مي مدهد.

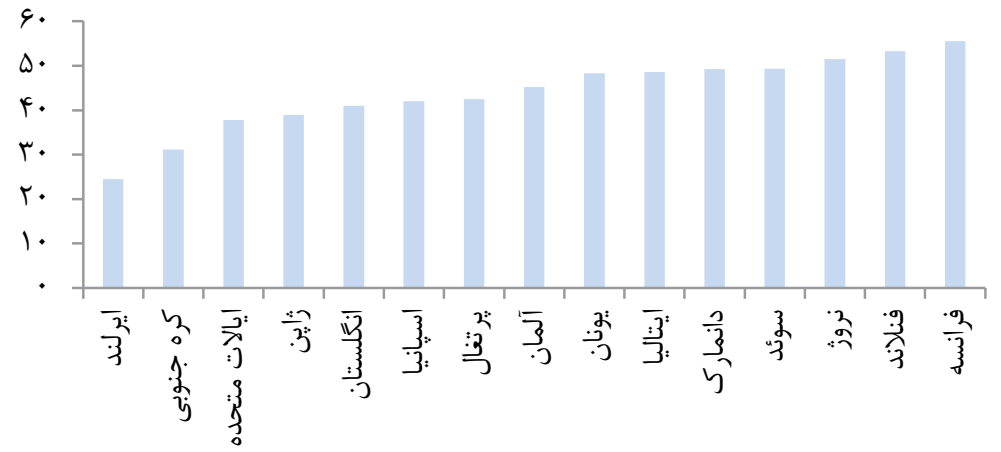

شكل ^: نسبت مخارج دولت به توليد ناخالص داخلى در كشورهاى منتخب

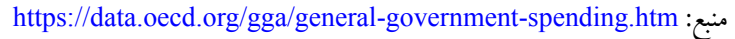

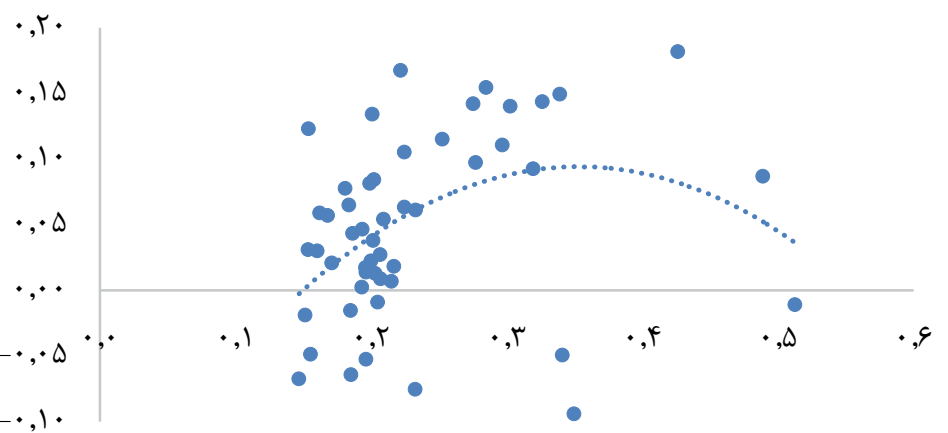

شكل 9: رابطه رشد اقتصادى با اندازه دولت (محور افقى: اندازه دولت، محور عمودى: رشد اقتصادى) 


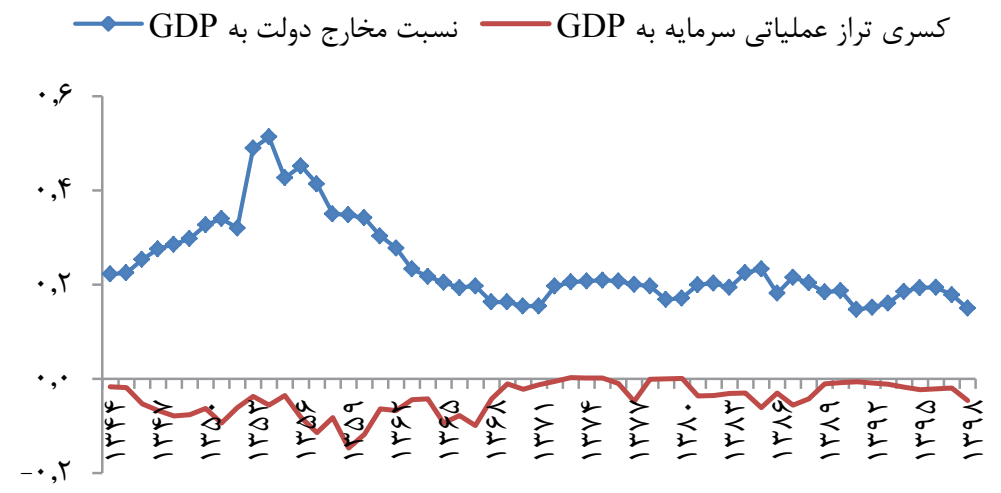

شكل • 1: نسبت تراز عملياتى و سرمايهاى به GDP و اندازه دولت

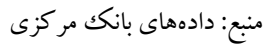

\section{متغير ها، دادهها، و تصريح الكو}

با توجه به ادبيات مربوط به عوامل موثر بر كسرى بودجه، مولفههاى اقتصادى و اقتصاد سياسى

$$
\text { به شرح زير جمعبندى مىشود: }
$$

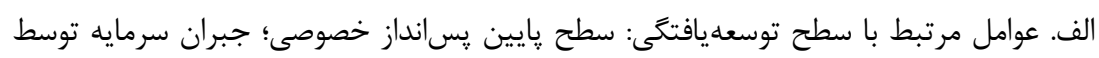

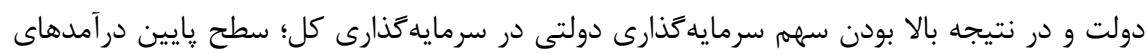

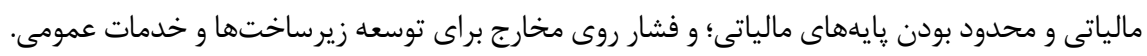

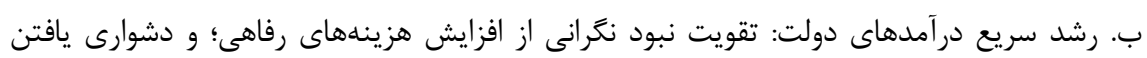

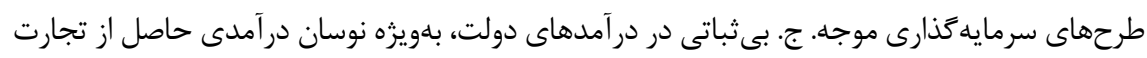

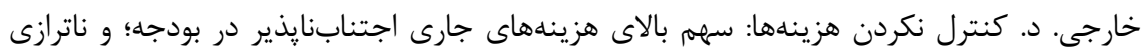

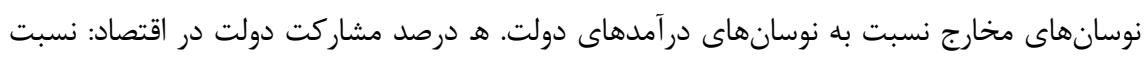

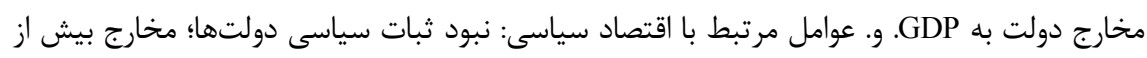

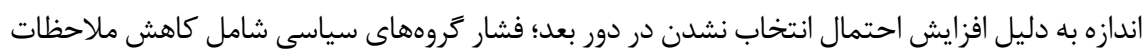

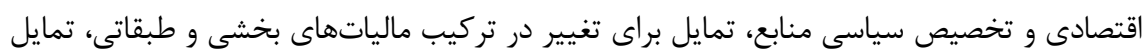

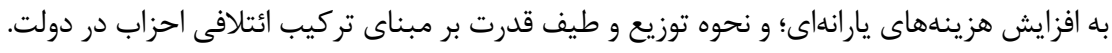

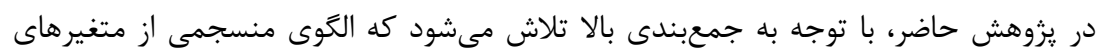


مختلف اقتصادى و اقتصاد سياسى موثر بر كسرى بودجه و شكستهاى ساختارى ناشى از شوكهاى

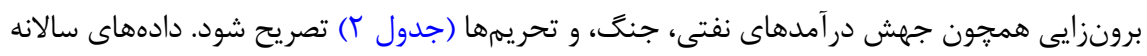

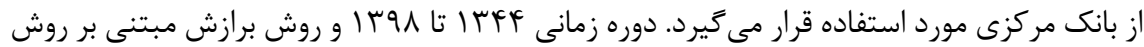
خودر گرسيونى با وقفههاى توزيعشده (ARDL) است.

جدول r: شرح متغيرهاى وابسته و مستقل و شاخصهاى مورد استفاده در الكو

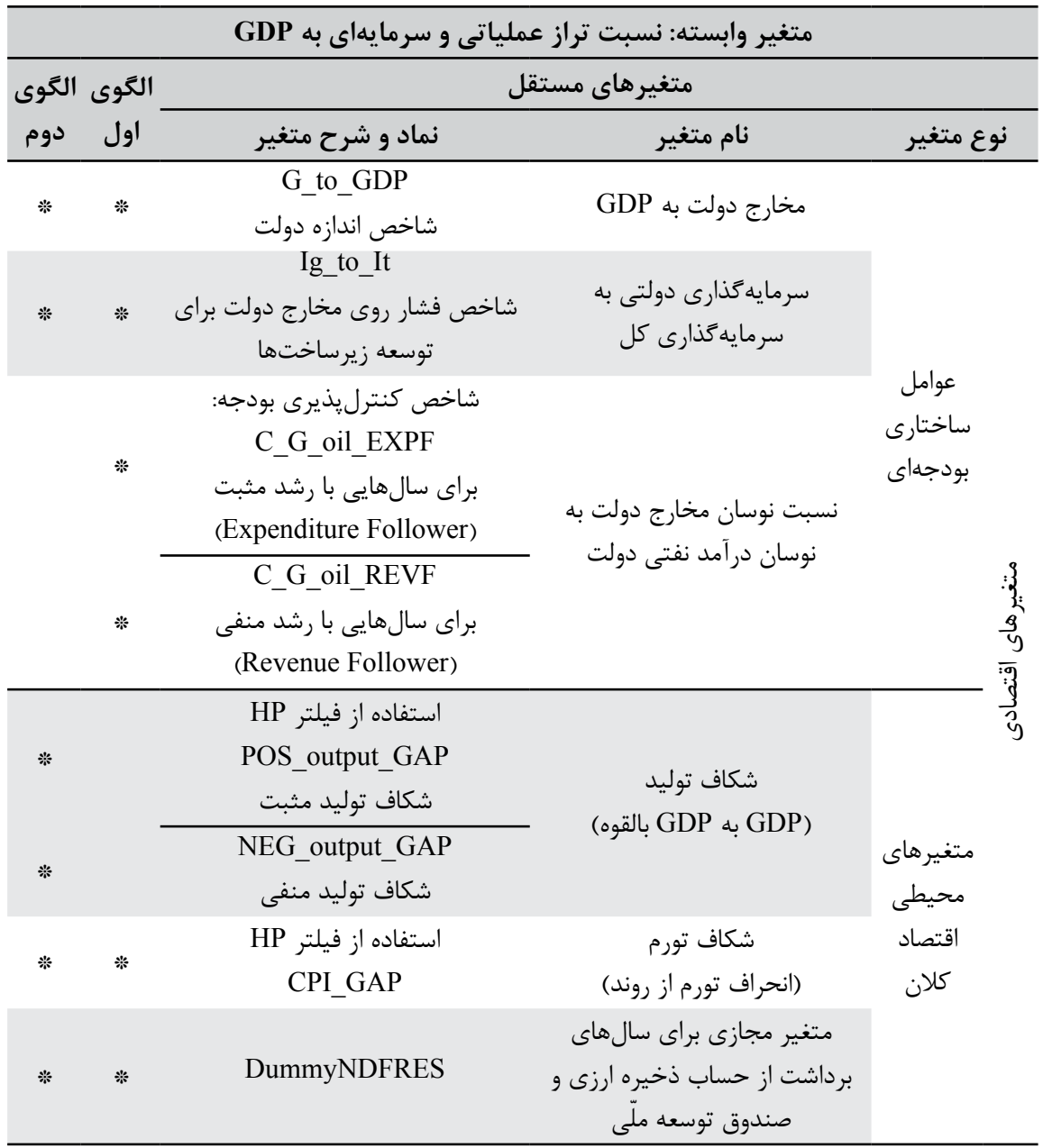


ادامه جدول r: شرح متغيرهاى وابسته و مستقل و شاخصهاى مورد استفاده در الكو

\begin{tabular}{|c|c|c|c|c|}
\hline \multicolumn{5}{|c|}{ متغير وابسته: نسبت تراز عملياتى و سرمايهاى به GDP } \\
\hline 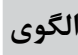 & 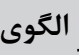 & & متغير هاى مستقل & \\
\hline 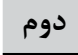 & 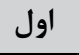 & نماد و شرح متغير & نام متغير & نوع متغير \\
\hline$*$ & $*$ & $\begin{array}{l}\text { شاخص نابرابرى_Poor } \\
\text { Rich }\end{array}$ & نسبت مخارج دهك يردرآمد به دمه مهر آمد & \\
\hline$*$ & $*$ & 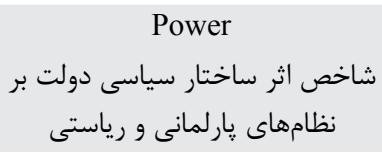 & شاخص قدرت دولت & متغيرهاى اقتصاد \\
\hline * & $*$ & 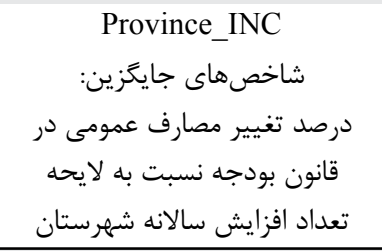 & فشار زروههاى سياسى & 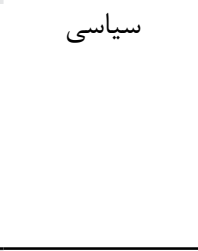 \\
\hline$*$ & * & War & متغير مجازى براى سالهاى جنَ & \\
\hline * & * & Oil_jump & متغير مجازى براىسالهاى جهشنفتى & 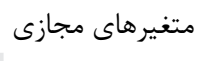 \\
\hline * & $*$ & Oil_sanctions & متغير مجازى براى سال هاى تحريم & \\
\hline
\end{tabular}

روش ساخت برخى متغيرهاى الكو به شرح زير است:

- نسبت نوسان مخارج دولت به نوسان درآمدهاى نفتى: اين نسبت به عنوان شاخص كنترليذير سيرى بودجه

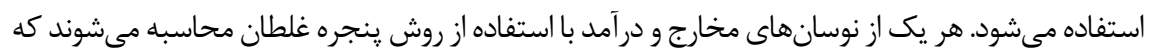

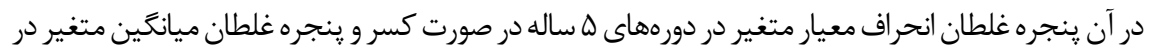

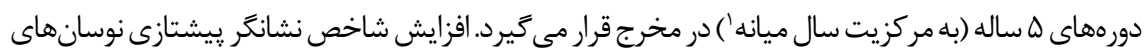

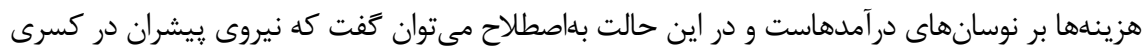

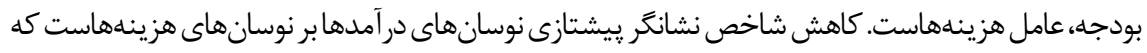
حاكى از يِيشران بودن عامل درآمدها در ايجاد كسرى بودجه است. براى تبيين نقش نوسانهاى هزينهاى و و

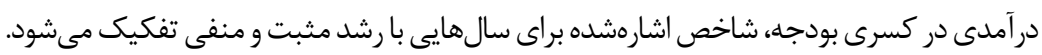

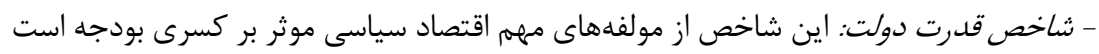

1. Centered Moving 
كه بر اساس ساختار سياسى دولت از جنبه تركيب احزاب و همجنين، وضعيت ثبات سياسى دولت تعريف مىشود. براى ساخت اين شاخص در ايران، براى دوره يیش از انقلاب كه نظام يارلمانى حاكم بوده، از طول عمر سياسى كابينها' و براى سالهاى پس از انقلاب كه نظام پارلمانى حاكم بوده، از تعداد استيضاح وزرا استفاده شده و بر اساس آن، شاخص قدرت كمّىسازى شده است (جداول بَ و ؟). جدول rا: شاخص قدرت بر اساس طول عمر كايينها در نظام يارلمانى (سالهاى ييش از انقلاب)

\begin{tabular}{|c|c|c|}
\hline عمر كابينه & 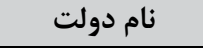 & 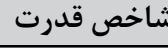 \\
\hline از شهريور qسا تا ارديبهشت · IrF & دولت شريفامامى & 1 \\
\hline تا VT تير |rF| & 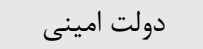 & 1 \\
\hline تا VV اسفند IFFY & دولت اعلم & r \\
\hline تا 9 بهمن سFس & دولت منصور & r \\
\hline تا مرداد وضهr| & دولت هويدا & r \\
\hline تا شهريور IraV & دولت آموزكار & r \\
\hline تا ها آبان Ir VV & دولت شريفامامى & 1 \\
\hline Irov & دولت ازهارى & 1 \\
\hline ا & دولت بختيار & 1 \\
\hline
\end{tabular}

جدول †: شاخص قدرت بر اساس تعداد استيضاح وزرا در نظام رياستى (سالهاى پِ از انقلاب)

\begin{tabular}{|c|c|c|}
\hline تعداد استيضاح & نام دولت & شاخص قدرت \\
\hline r & دولت موسوى & r \\
\hline f & دولت هاشمى & r \\
\hline V & دولت خاتمى & r \\
\hline v & دولت احمدىنزاد & r \\
\hline 1. & دولت روحانى & 1 \\
\hline
\end{tabular}

- شكاف توليد: براى تبيين رابطه كسرى بودجه با جرخههاى رونق و ركود، متغير شكاف توليد

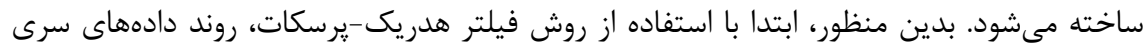

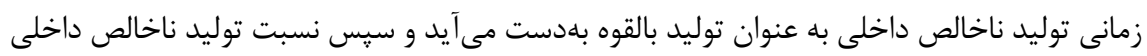

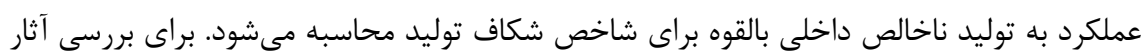


ادوار تجارى بر كسرى بودجه، سالهاى شكاف توليد مثبت (رونق) و شكاف منفى (ركود) از هم

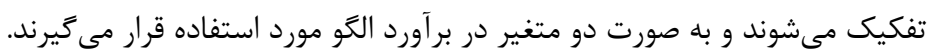

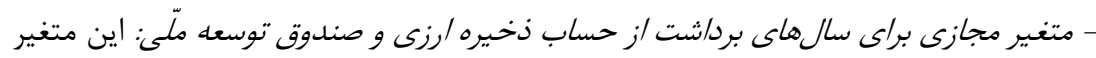
براى تبيين اثر ثروت بر بودجه دولت و كسرى بودجه منظور مىشود. فرض آن است كه در سالهايى

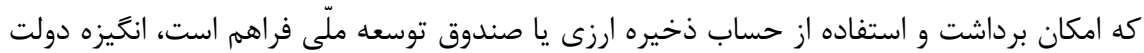
براى افزايش مخارج و در نتيجه، كسرى بودجه وجود دارد.

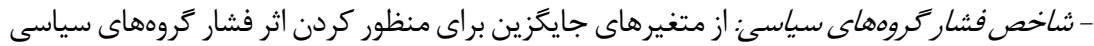
بر شكلىيرى كسرى بودجه درصد تغيير مصارف بودجه عمومى توسط مجلس (قانون بودجه) نسبت به

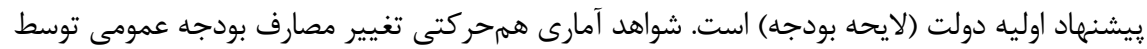
مجلس، بلويزه مخارج جارى دولت را با كسرى بودجه تاييد مى كند. همجنين، افزايش سالانه تعداد

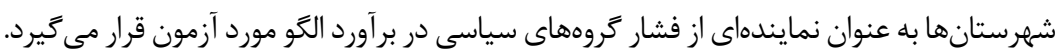

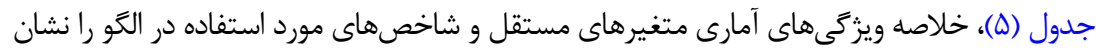

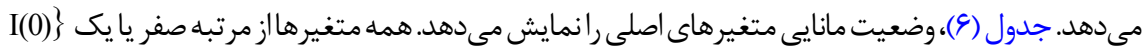
يا (1) مانا هستند و در صورت همجمعى، انتظار مىرود ارتباط بلندمدت ميان متغيرها وجود داشته باشد.

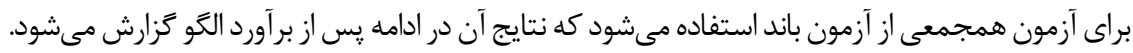

جدول ه: خلاصه ويز تىهاى آمارى متغيرهاى مستقل و شاخصهاى مورد استفاده در التو

\begin{tabular}{|c|c|c|c|c|c|}
\hline بيشينه & كمينه & انحراف از معيار & ميانگين & تعداد مشاهدهها & نماد متغير \\
\hline 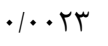 & $-\cdot|| F V \mid$ & $\cdot / \cdot$ TFAN & $-.1 \cdot$ FTs & $\Delta \Delta$ & DEFIC_to_GDP \\
\hline$\cdot|\Delta| r \mid$ & . /1499V & $\cdot / \cdot 19$. & $\cdot / T F I D$ & $\Delta \Delta$ & G_To_GDP \\
\hline$\cdot / 4 \vee V \wedge$ & $\cdot / 194$. & .1 .990 & $\cdot 1 / 199$ & $\Delta \Delta$ & Ig_To_It \\
\hline$\cdot / T V \Lambda$. & $-\cdot / T F \Lambda$. & .।. V१V & $-1 \cdot e l / f f$ & $\Delta \Delta$ & CPI_GAP \\
\hline I/Irrq & . & . IDTYY & $.101 \mathrm{VH}$ & $\Delta F$ & POS_output_GAP \\
\hline$\cdot / 9911$ & · & •/4^१ฬ & ./4Arq & $\Delta F$ & NEG_output_GAP \\
\hline 1/Irrq & .|Arq| & $\cdot 1 \cdot 0 \cdot 1$ & $1 / \cdot \cdot 14$ & $\Delta F$ & Exp_NEW_GAP \\
\hline 离 & $I T / K$ & $\Delta / \cdot \vee \wedge q$ & IV/ATV & $\Delta \cdot$ & Rich_Poor \\
\hline rq & -1 & $V / F \Delta \Delta q$ & $\Delta / V 1 \& 9$ & $\Delta r$ & Province_Inc \\
\hline r & · & IVETA & 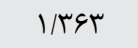 & $\Delta \Delta$ & Power_Break \\
\hline r & 1 & - IAFFA & $r / . q \cdot q$ & $\Delta \Delta$ & Power \\
\hline ( וTMK/ & • & . &.$/ \cdot F \Delta V$ & $\Delta \Delta$ & DummyNDFRES \\
\hline
\end{tabular}


جدول 9: وضعيت مرتبه مانايى و نامانايى متغيرها

\begin{tabular}{|c|c|c|c|}
\hline مانايى / نامانايى & نام متغير & \multicolumn{2}{|c|}{ نوع متغير } \\
\hline $\mathrm{I}(0)$ & ADJ & \multicolumn{2}{|c|}{ ضريب تعديل } \\
\hline $\mathrm{I}(1)$ & $\mathrm{G}$ to $\mathrm{GDP}$ & \multirow{5}{*}{ كوامل ساختارى بودجه } & \multirow{10}{*}{ اقتصادى } \\
\hline $\mathrm{I}(1)$ & Ig_to_It & & \\
\hline $\mathrm{I}(0)$ & C_G_OIL & & \\
\hline $\mathrm{I}(0)$ & C_G_oil_REVF & & \\
\hline $\mathrm{I}(0)$ & C G oil EXPF & & \\
\hline $\mathrm{I}(0)$ & *y_to_y & \multirow{5}{*}{ شترايط محيط } & \\
\hline $\mathrm{I}(0)$ & POS_output_GAP & & \\
\hline $\mathrm{I}(0)$ & NEG_output_GAP & & \\
\hline $\mathrm{I}(0)$ & CPI_GAP & & \\
\hline $\mathrm{I}(1)$ & DummyNDERES & & \\
\hline $\mathrm{I}(1)$ & Power & \multirow{4}{*}{\multicolumn{2}{|c|}{ تصاد سياسى }} \\
\hline $\mathrm{I}(1)$ & Power_Break & & \\
\hline $\mathrm{I}(0)$ & Province_Inc & & \\
\hline $\mathrm{I}(1)$ & Rich Poor & & \\
\hline
\end{tabular}

بر آورد الكوهاى يزوهش

با توجه به اينكه از ميان متغيرهاى توضيحدهنده، دو متغير شكاف توليد (به عنوان متغير شرايط

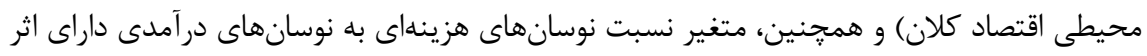
جايگزين در كسرى بودجه هستند، بنابراين دو الكَ شامل الكَى اول (با تاكيد بر نسبت نوسانهاى

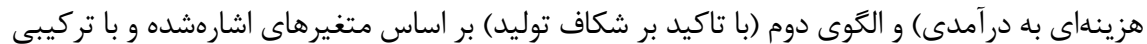

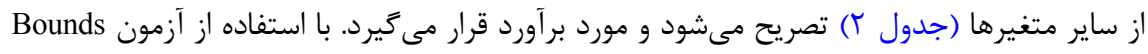

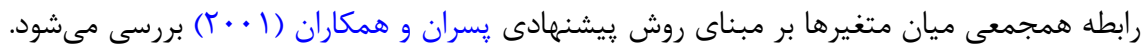

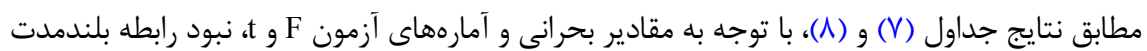
ميان متغيرها يعنى فرض صفر (H ) رد مىشود. براى تعيين وقفه بهينه متغيرها از روش 'AIC استفاده

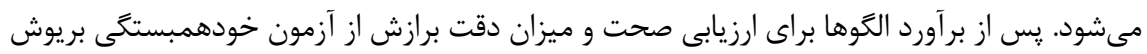

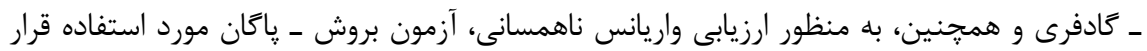

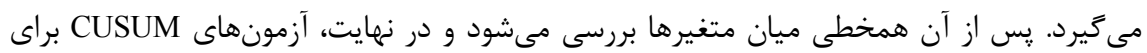


آزمون ثبات برازش بررسى مى گردد. جداول (9) و ( •()، نتايج برآورد ضرايب بلندمدت، و جدول (1)، ضر ايب تحصيح خطا را بهترتيب در الكوهاى اول و دوم نشان مى دهند.

\begin{tabular}{|c|c|c|c|c|c|c|}
\hline \multicolumn{2}{|c|}{$\% 99$} & \multicolumn{2}{|c|}{$\% 9 \Delta$} & \multicolumn{2}{|c|}{$\% 9}$. & \multirow[t]{2}{*}{ مقادير بحرانى } \\
\hline $\mathrm{I}(1)$ & $\mathrm{I}(0)$ & $\mathrm{I}(1)$ & $\mathrm{I}(0)$ & $\mathrm{I}(1)$ & $\mathrm{I}(0)$ & \\
\hline $91 \cdot 10$ & س & F/FTV & $r / \Lambda \cdot I$ & T/VAT & T/TKT & F آماره F \\
\hline$-\Delta / \cdot r q$ & -r/QTV & $-F / \mid F \lambda$ & $-Y / V \wedge \varphi$ & $-r / V I \cdot$ & $-T / 419$ & آماره t \\
\hline
\end{tabular}

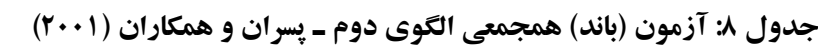

\begin{tabular}{|c|c|c|c|c|c|c|}
\hline \multicolumn{2}{|c|}{$\% 99$} & \multicolumn{2}{|c|}{$\% 90$} & \multicolumn{2}{|c|}{$\% 9}$. & مقادير بحرانى \\
\hline $\mathrm{I}(1)$ & $\mathrm{I}(0)$ & $\mathrm{I}(1)$ & $\mathrm{I}(0)$ & $\mathrm{I}(1)$ & $\mathrm{I}(0)$ & \\
\hline$F / 1 \Lambda$ & r/৭९ & $r / v q$ & $r / 9 T$ & D/r & $T / T \varphi$ & آماره F \\
\hline$f / 4 q$ & س/ו & $4 / 19$ & r/AS & r/AS & T/QV & t t to to \\
\hline
\end{tabular}

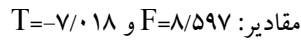

جدول 9: نتايج بر آورد ضرايب الكوى اول

\begin{tabular}{|c|c|c|c|c|c|c|c|c|c|c|c|}
\hline \multicolumn{12}{|c|}{ متغير وابسته: DEFIC_to_GDP } \\
\hline $\begin{array}{r}\text { Power_ } \\
\text { Break } \\
\end{array}$ & Power & $\begin{array}{l}\text { CPI_- } \\
\text { GAP } \\
\end{array}$ & $\begin{array}{c}\text { DummyN } \\
\text { DFRES } \\
\end{array}$ & $\begin{array}{c}\text { Rich_- } \\
\text { Poor } \\
\end{array}$ & War & $\begin{array}{c}\text { Ig_to_- } \\
\text { It } \\
\end{array}$ & $\begin{array}{c}\text { C_G_oil_ } \\
\text { REVF }\end{array}$ & $\begin{array}{c}\text { C_G_oil_ } \\
\text { EXPF }\end{array}$ & $\begin{array}{c}\text { G/) } \\
\text { (GDP } \\
\end{array}$ & ADJ & \\
\hline \multirow{8}{*}{$\begin{array}{l}\cdot \cdot \cdot \cdot F T \\
(\cdot / \cdot 1 \cdot)\end{array}$} & .1 .4$. & & & $-\cdot 1 \cdot \cdot \Delta$ & & & $\cdot / \cdot \Delta \varphi$ & $-\cdot 11 \cdot 0$ & $-\cdot / T V \wedge$ & $-1 / 94$ & \\
\hline & $(\cdot / \cdot 1 r)$ & & & $(\cdot / \cdot r)$ & & & $(\cdot / \cdot r l)$ & $(\cdot / \cdot f \mid)$ & $(\cdot / \cdot r \Delta)$ & $(\cdot / r \Delta Y)$ & \\
\hline & & & - & & $-.1 \cdot F V$ & $-\cdot / l \Delta V$ & $\cdot \mid \cdot v 1$ & $-\cdot / 111$ & - & $-1 / \Delta r$ & \\
\hline & & & $(\cdot / \cdot r \wedge)$ & & $(\cdot / \cdot v v)$ & $(\cdot / 1 \cdots)$ & $(\cdot / \cdot r \varphi)$ & $(\cdot / \cdot r V)$ & $(\cdot / \cdot r \varepsilon)$ & $(\cdot / K \mid Y)$ & \\
\hline & & & $-.1 .9 q$ & & $-.1 \cdot 4 \varphi$ & & $.1 .4 q$ &.$- / .9$. & $-\cdot / r \wedge 9$ & $-1 / 4$ & \\
\hline & & & $(\cdot / \cdot r \Delta)$ & & $(\cdot / \cdot \cdot 9)$ & & $(\cdot / \cdot \mid \mathrm{V})$ & $(\cdot / \cdot r \cdot)$ & $(\cdot / \cdot T V)$ & $(\cdot / r)$ & \\
\hline & &.$- / \cdot 1 r$ &.$- / .9 V$ & & $-\cdot 1 \cdot f F$ & & .1 .49 & -.1 .99 & $-\cdot r \cdot r$ & $-1 / 4 \varepsilon$ & \\
\hline & & $(\cdot / \cdot \Delta F)$ & $(\cdot / \cdot r \Delta)$ & & $(\cdot / \cdot \cdot \varphi)$ & & $(\cdot / \cdot \mid \mathrm{V})$ & $(\cdot / \cdot r I)$ & $(\cdot / . r q)$ & $(\cdot / r \cdot V)$ & \\
\hline.$- / \cdot F T$ &.$/ \cdot f$. & & & $-\cdot 1 \cdot \cdot \Delta$ & & & $\cdot / \cdot \Delta G$ & $-\cdot / 1 \cdot \Delta$ & $-\cdot / T V \Lambda$ & $1 / 94$ & \\
\hline$(\cdot / \cdot 1 \cdot)$ & $(\cdot / \cdot \mid r)$ & & & $(\cdot / \cdot r)$ & & & $(\cdot / \cdot r \mid)$ & $(\cdot / \cdot F \mid)$ & $(\cdot / \cdot r \Delta)$ & $(\cdot / r \Delta Y)$ & \\
\hline
\end{tabular}

(ارقام داخل يرانتز Se (است) 
جدول • ا: نتايج بر آورد ضر ايب التوى دوم

\section{متغير وابسته: DEFIC_to_GDP}

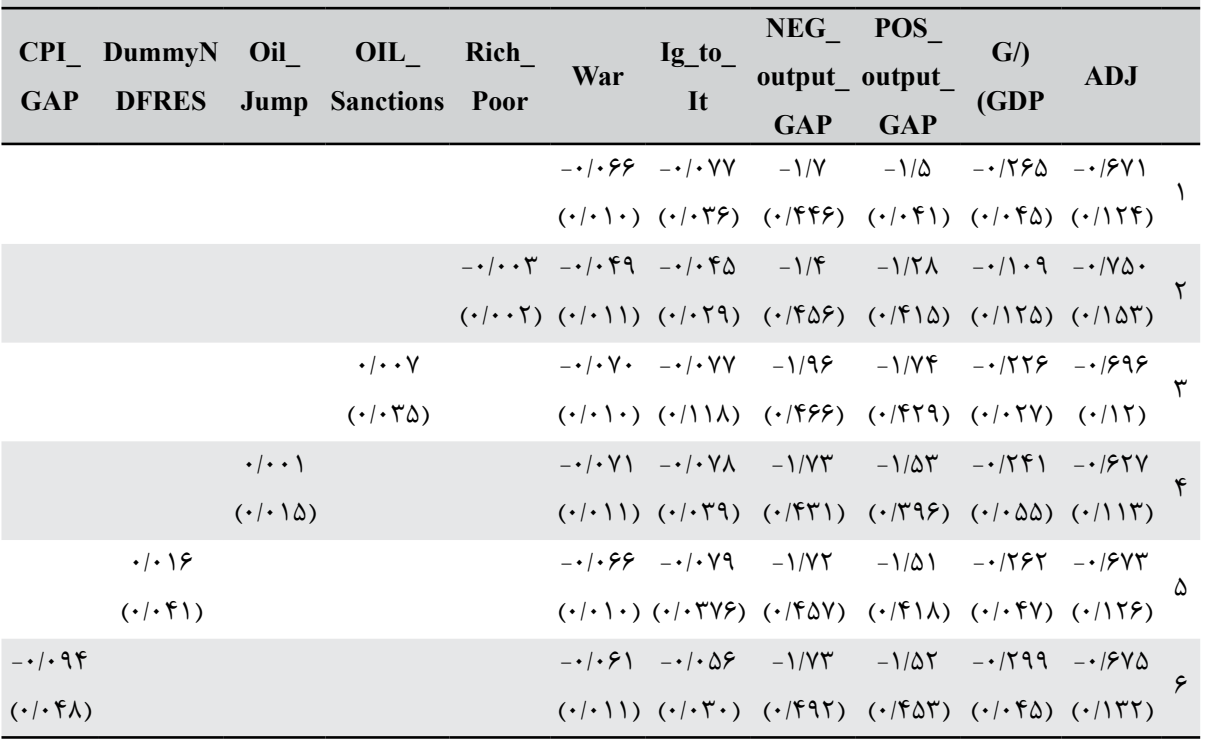

(ارقام داخل يرانتز Se (است)

جدول 11: ضريب تحصيح خطا در التوهاى اول و دوم

\begin{tabular}{|c|c|c|c|c|c|c|}
\hline ضريب & خطاى استاندارد & آماره t & $\mathbf{P}>|\mathbf{t}|$ & 9 ٪ اطمينان) & بازه ضرايب & \\
\hline$-1 / 4 \cdot F \Delta q 1$ & $\cdot / r \cdot \cdot||^{f}$ & $-V / \cdot r$ & $\cdot / \cdots$ & -I/ATHF & $-\cdot / 9 \wedge \Delta \varphi$ & الكَوى اول \\
\hline$-\cdot 19 V 11$ & - IITFAG & $-\Delta / r \Lambda$ & $\cdot 1 \cdots$ & -. 9 TVR & $-\cdot|c| \Delta \Lambda$ & الخوى دوم \\
\hline
\end{tabular}

\section{بحث و نتيجه كيرى}

در طى ساليان كذشته، همواره كسرى بودجه به عنوان يك يديده ثابت در اقتصاد ايران

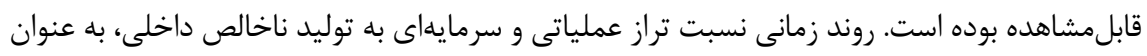

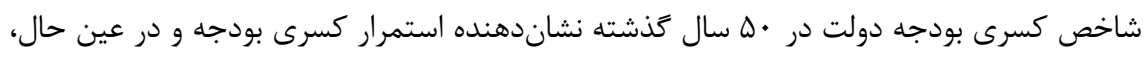
نوسان شديد دامنه مقدار آن نسبت به مقياس توليد ناخالص داخلى كشور است. نبود توانايى دولتها دانها در حفظ توازن بين منابع و مصارف در بودجه در بيشتر سالها بيانگر انباشت بدهى و نايايدارى در 
بودجه است. به منظور اصلاح ساختار بودجه عمومى دولت، شناخت ويثگى هاى بودجه و عوامل موثر بر كسرى بودجه دولت ضرورى است. هدف اين يزوهش، شناسايى مهمترين موارد موثر بر ناترازى بودجه دولت در اقتصاد ايران است. به اين منظور در تبيين كسرى بودجه مزمن سه مجموعه عوامل ساختارى بودجه، شرايط محيطى اقتصاد

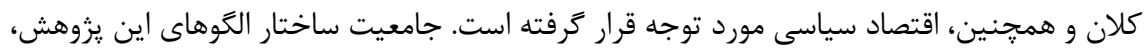
مهممترين تفاوت آن با ساير يروهشهاى تجربى است. بنابراين، با مرورى بر مشخصه هاى بودجه،، عوامل

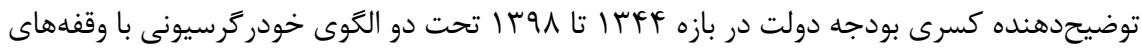

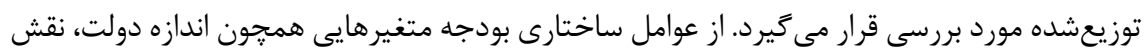

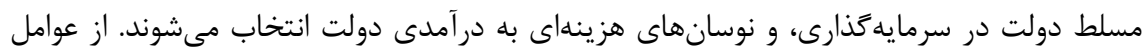
اقتصاد كلان متغيرهايى همجون وضعيت ادوار تجارى، شكاف تورم، شرايط صندوق توسعه، و حساب ذخيره ارزى مورد توجه قرار مى گيرند. از متغيرهاى اقتصاد سياسى شاخص نابرابرى، شاخص قدرت مدئ

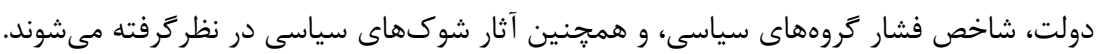
نتايج الكوهاى يزوهش نشان مى دهد كه با افزايش اندازه دولت (نسبت مخارج عمومى دولت به GDP) شاخص كسرى بودجه (نسبت كسرى بودجه به توليد ناخالص داخلى) افزايش مىيابد. همجنين، افزايش سهم سرمايهگذارى دولتى از سرمايهگذارى كل، اثر افزايشى بر شاخص كسرى بـى

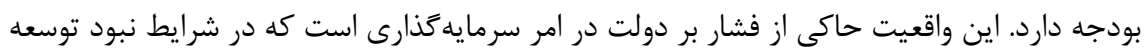
بخش خصوصى به افزايش كسرى بودجه منجر مىشود.

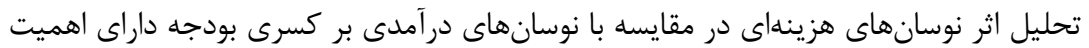

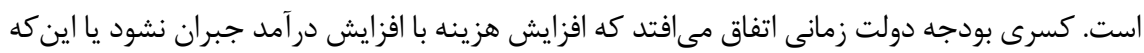
كاهش درآمد با كاهش متناسب هزينه همراه نباشد. بدين جهت در الكوى برآوردى، متغير نسبت هيت

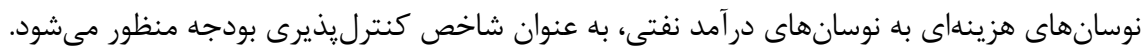
رشد مثبت اين نسبت نشانكً تسلط نوسانهاى هزينهاى و رشد منفى آن نشانكر تسلط نوسانهاى

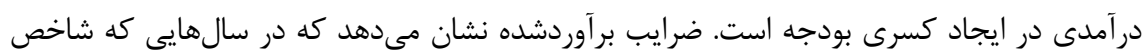

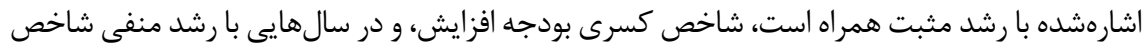
كسرى بودجه كاهش دارد. بنابراين، مىتوان كفت كه در اقتصاد ايران نيروى ييشران در كسرى بودجه،

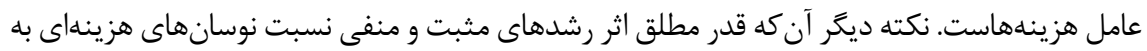

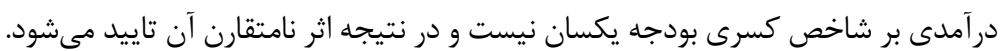


مطابق نتايج الكَى يزوهش، اثر ادوار تجارى بر كسرى بودجه ايران مورد توجه است. همجنان كه در ادبيات نظرى و تجربى مطالعه حاضر كذشت، رفتار كسرى بودجه در كشورهاى توسعهيافته

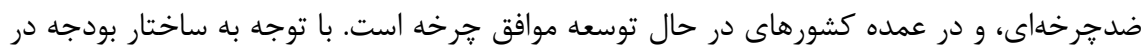
اقتصاد ايران با ويزگى مهم وابستكى نفتى، در دوران رونق اقتصادى (نسبت GDP به GDP بالقوه بزرگتر از يك) كسرى بودجه داراى رفتار موافق جرخه، و در دوران ركود داراى رفتار ضدجرخه خهاى

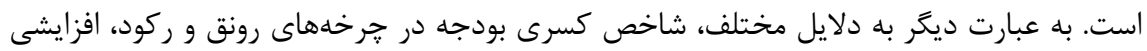

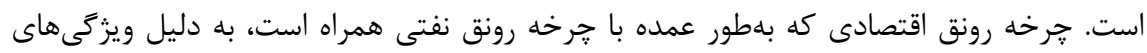

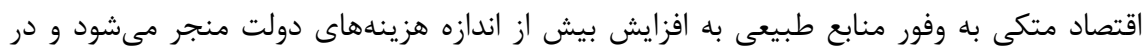
نهايت كسرى بودجه را مىافزايد. در دوران ركود اقتصادى كه با كاهش در آمدهاى نفتى همراه استى است،

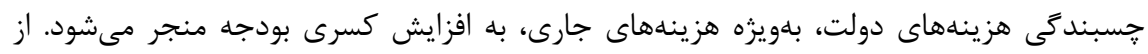
عوامل موثر ديكر بر كسرى بودجه، وضعيت نابر ابرى توزيع در آمد است كه از راه شكل تهيرى انخيزههاى

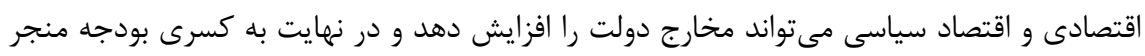

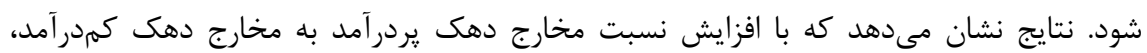
شاخص كسرى بودجه افزايش مىيابد. همجنين، اثر دو مولفه اقتصاد سياسى، يعنى شاخص قدرت دولت و فشار گروههاى سياسى را بر كسرى بودجه تاييد مى كند. هر دو مولفه بلهترتيب نشاندهنده افزايش بىثباتى در ساختار سياسى دولت و حضور احزاب و ذىنفعان مختلف با ترجيحات غيرهمًن در مورد تركيب مخارج عمومى، و وجود تعارض منافع در مورد منابع عمومى، بهويزه تعارضهاى بازتوزيعى است كه در نهايت به كنترلنايذيرى كسرى بودجه منجر مىشود.

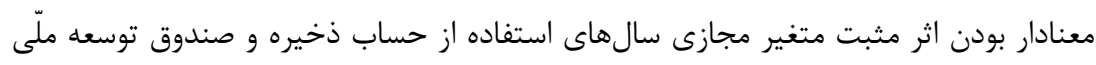

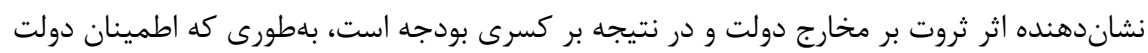

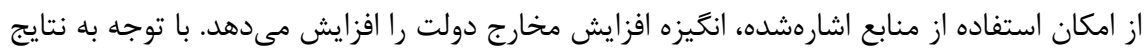
يزوهش، مهممترين توصيه سياستى براى كنترليذيرى كسرى بودجه دولت، تعريف قواعد مالى است.

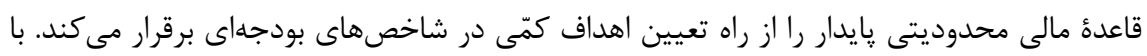
برقرارى اين محدوديتها، مقادير تعيينشده در دوره زمانى مورد نظر تغييريذير نيست و راهنمايى راهيى

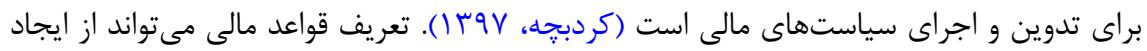
اخلال مالى، به دليل فشار گروههاى سياسى براى مخارج اضافى جلوكيرى كند و پايدارى مالى مالى دولت را از راه تعيين سقف كسرى بودجه و ايجاد محدوديت در استقراض دولت افزايش دهد. اين نكته از برائ 


$$
\begin{aligned}
& \text { آن جهت داراى اهميت است كه در سالهاى اخير امكان تامين مالى دولت از بازار بدهى از راه روش } \\
& \text { انتشار اوراق قرضه فراهم شده است. در شرايط نبود قواعد مالى، گرفتارى دولت در تلدبازى يونزى دور }
\end{aligned}
$$

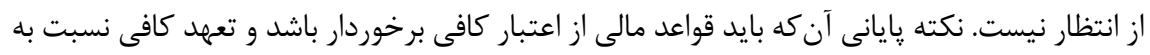

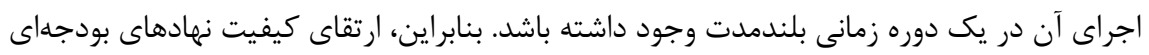

$$
\begin{aligned}
& \text { از الزامهاى ييادهسازى موفق قواعد مالى است. }
\end{aligned}
$$

Abell, J. D. (1990). Twin Deficits During the 1980s: An Empirical Investigation. Journal of Macroeconomics, 12(1), 81-96. https://doi.org/10.1016/0164-0704(90)90057-H

Agnello, L., \& Sousa, R. M. (2009). The Determinants of Public Deficit Volatility. European Central Bank (ECB) Working Paper, No. 1042.

Alesina, A., \& Perotti, R. (1999). Budget Deficits and Budget Institutions, in; Poterba, J., von Hagen, J.(Eds), Fiscal Institutions and Fiscal Performance NBER. In: University of Chicago Press.

Alesina, A., \& Tabellini, G. (1990a). A Positive Theory of Fiscal Deficits and Government Debt. The Review of Economic Studies, 57(3), 403-414. https://doi.org/10.2307/2298021

Alesina, A., \& Tabellini, G. (1990b). Voting on the Budget Deficit. American Economic Review, 80(1), 37-49.

Alesina, A., \& Tabellini, G. (2005). Why Is Fiscal Policy Often Procyclical? NBER Working Paper, NO 11600.

Alesina, A., Campante, F. R., \& Tabellini, G. (2008). Why is Fiscal Policy Often Procyclical? Journal of the European Economic Association, 6(5), 1006-1036. https://doi.org/10.1162/JEEA.2008.6.5.1006

Alt, J.E., \& Lassen, D. D. (2006). Fiscal Transparency, Political Parties, and Debt in OECD Countries. European Economic Review, 50(6), 1403-1439. https://doi.org/10.1016/j.euroecorev.2005.04.001

Alt, J. E., \& Lowry, R. C. (1994). Divided Government, Fiscal Institutions, and Budget Deficits: Evidence from the States. American Political Science Review, 88(4), 811-828. https://doi.org/10.2307/2082709

Auerbach, A. J., \& Kotlikoff, L. J. (1987). Dynamic Fiscal Policy: Cambridge University Press.

Baron, D. P., \& Ferejohn, J. A. (1989). Bargaining in Legislatures. The American Political Science Review, 83(4), 1181-1206. https://doi.org/10.2307/1961664

Barro, R. J. (1974). Are Government Bonds Net Wealth? Journal of Political Economy, 82(6), 1095-1117. https://doi.org/10.1086/260266

Barro, R. J. (1989). The Ricardian Approach to Budget Deficits. Journal of Economic Perspectives, 3(2), 37-54. https://doi.org/10.1257/jep.3.2.37

Bernheim, B. D. (1987). Ricardian Equivalence: An Evaluation of Theory and Evidence. 
NBER Macroeconomics Annual, 2(1), 263-304.

Bluedorn, J., \& Leigh, D. (2011). Revisiting the Twin Deficits Hypothesis: The Effect of Fiscal Consolidation on the Current Account. IMF Economic Review, 59(4), 582-602. https://doi.org/10.1057/imfer.2011.21

De Haan, J., \& Klomp, J. (2013). Conditional Political Budget Cycles: A Review of Recent Evidence. Public Choice, 157(3-4), 387-410. https://doi.org/10.1007/s11127-013-0106-6

De Haan, J., \& Sturm, J.-E. (1997). Political and Economic Determinants of OECD Budget Deficits and Government Expenditures: A Reinvestigation. European Journal of Political Economy, 13(4), 739-750. https://doi.org/10.1016/S0176-2680(97)00033-5

Diamond, P. A. (1965). National Debt in a Neoclassical Growth Model. The American Economic Review, 55(5), 1126-1150.

Dindarrostami, M., Shirinbakhsh, S., \& Afshari, Z. (2020). Investigating Factors Affecting Cyclical and Structural Budget Deficit in Iran. Journal of Applied Economics Studies in Iran, 9(33), 199-225. https://dx.doi.org/10.22084/aes.2020.19634.2912

Eisner, R. (1989). Budget Deficits: Rhetoric and Reality. Journal of Economic Perspectives, 3(2), 73-93. https://doi.org/10.1257/jep.3.2.73

Eslava, M. (2011). The Political Economy of Fiscal Deficits: A Survey. Journal of Economic Surveys, 25(4), 645-673. https://doi.org/10.1111/j.1467-6419.2010.00647.x

Fatahi, S., Heydari Dizgarani, A., \& Askari, E. (2014). The Study of Government Debt Sustainability in Iran's Economy. Quarterly Journal of Fiscal and Economic Policies, 2(6), 67-86. http://qjfep.ir/article-1-152-en.html

Gavin, M., \& Perotti, R. (1997). Fiscal Policy in Latin America. NBER Macroeconomics Annual, 12(1), 11-61. https://doi.org/10.2307/3585216

Hagemann, R. (1999). The Structural Budget Balance The IMF's Methodology. International Monetary Fund Working Paper No. 99/95.

Hagen, J. v. (2002). Fiscal Rules, Fiscal Institutions and Fiscal Performance. The Economic and Social Review, 33(3), 263-284.

Holmes, M. J. (2010). A Reassessment of the Twin Deficits Relationship. Applied Economics Letters, 17(12), 1209-1212. https://doi.org/10.1080/00036840902845434

Irwin, T. C. (2015). Defining the Government's Debt and Deficit. Journal of Economic Surveys, 29(4), 711-732. https://doi.org/10.1111/joes.12123

Kaminsky, G. L., Reinhart, C. M., \& Végh, C. A. (2004). When It Rains, It Pours: Procyclical Capital Flows and Macroeconomic Policies. NBER Macroeconomics Annual, 19(1), 11-53.

Komijani, A., \& Varhrami, V. (2012). Assessing the Role of Various Factors Causing Budget Deficit in Iran. Rahbord, 21(64), 27-42. http://rahbord.csr.ir/article_124446.html

Krogstrup, S., \& Wyplosz, C. (2010). A Common Pool Theory of Supranational Deficit Ceilings. European Economic Review, 54(2), 269-278. https://doi.org/10.1016/j.euroecorev.2009.06.010

Lucas, R. E. (1973). Some International Evidence on Output-Inflation Tradeoffs. The American Economic Review, 63(3), 326-334.

Maltritz, D., \& Wüste, S. (2015). Determinants of Budget Deficits in Europe: The Role and Relations of Fiscal Rules, Fiscal Councils, Creative Accounting and the Euro. Economic Modelling, 48(1), 222-236. https://doi.org/10.1016/j.econmod.2014.12.001

Mawejje, J., \& Odhiambo, N. M. (2020). The Determinants of Fiscal Deficits: A Survey of Literature. International Review of Economics, 67(3), 403-417. 
https://doi.org/10.1007/s12232-020-00348-8

Morrison, T. K. (1982). Structural Determinants of Government Budget Deficits in Developing Countries. World Development, 10(6), 467-473. https://doi.org/10.1016/0305-750X(82)90003-1

Mowlaei, M., \& Abdian, M. (2018). Determinants of Government's Budget Deficit in Iran: 1989-2015. The Journal of Planning and Budgeting, 23(1), 59-78. http://jpbud.ir/article-1-1681-en.html

Nordhaus, W. D. (1975). The Political Business Cycle. The Review of Economic Studies, 42(2), 169-190. https://doi.org/10.2307/2296528

Pesaran, M. H., Shin, Y., \& Smith, R. J. (2001). Bounds Testing Approaches to the Analysis of Level Relationships. Journal of Applied Econometrics, 16(3), 289-326. https://doi.org/10.1002/jae.616

Roubini, N. (1991). Economic and Political Determinants of Budget Deficits in Developing Countries. Journal of International Money and Finance, 10(1), 49-72. https://doi.org/10.1016/0261-5606(91)90046-M

Roubini, N., \& Sachs, J. D. (1989). Political and Economic Determinants of Budget Deficits in the Industrial Democracies. European Economic Review, 33(5), 903-933. https://doi.org/10.1016/0014-2921(89)90002-0

Seater, J. J. (1993). Ricardian Equivalence. Journal of Economic Literature, 31(1), 142-190.

Talvi, E., \& Vegh, C. A. (2005). Tax Base Variability and Procyclical Fiscal Policy in Developing Countries. Journal of Development Economics, 78(1), 156-190. https://doi.org/10.1016/j.jdeveco.2004.07.002

Tanzi, V. (2000). The Role of the State and the Quality of the Public Sector. En: XII Seminario Regional de Política Fiscal: Compendio de documentos-Santiago: CEPAL, 2000-p. 3-21.

Weingast, B. R., Shepsle, K. A., \& Johnsen, C. (1981). The Political Economy of Benefits and Costs: A Neoclassical Approach to Distributive Politics. Journal of Political Economy, 89(4), 642-664. http://dx.doi.org/10.1086/260997

$$
\begin{aligned}
& \text { ب) فارسى } \\
& \text { جهرازى مدرسه، سرور، و نجاتى، مهدى (צو (1). اثر بدهى هاى عمومى و بهرهورى بر رشد اقتصادى در ايران. }
\end{aligned}
$$

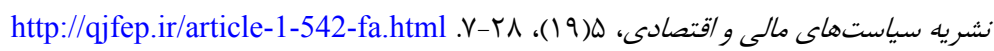

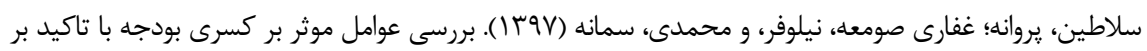

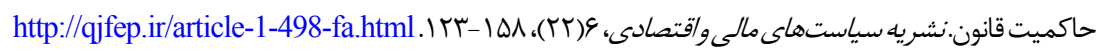

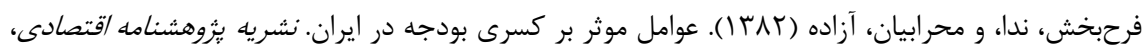

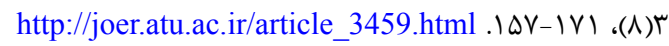

$$
\begin{aligned}
& \text { كردبجه،، محمد (Vو (I)). بودجه و قاعدهمندى سياست مالى: طرح جامع مطالعات اقتصاد /يران. انتشارات }
\end{aligned}
$$

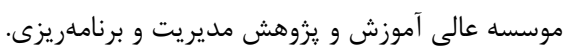

